STONE CENTER ON SOCIO-ECONOMIC INEQUALITY

WORKING PAPER SERIES

No. 10

Class Position and Political Opinion in Rich Democracies

Arvid Lindh

Leslie McCall

February 2020

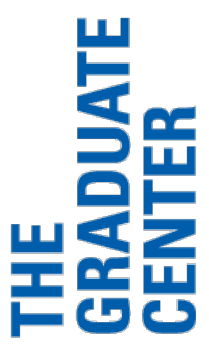

CITY UNIVERSITY

OF NEW YORK 


\title{
Class Position and Political Opinion in Rich Democracies
}

\author{
Arvid Lindh \\ Swedish Institute for Social Research \\ Stockholm University \\ arvid.lindh@sofi.su.se \\ Leslie McCall \\ Stone Center on Socio-Economic Inequality \\ The Graduate Center, City University of New York \\ 1mccall@gc.cuny.edu
}

\begin{abstract}
In many high-income countries today, scholarly interest in the politics of class has coincided with growing economic inequality, rising support for non-mainstream political parties and candidates, and increasing flows of immigration. We review social science research on the views of different class segments vis-à-vis economic, political, and sociocultural issues, finding greater scholarly attention to the interdependence of economic, social, and political concerns and preferences than arguably was the case even a few years ago. Our main aim is to synthesize and critically evaluate this rapidly expanding literature, but we also provide empirical data on class differences and similarities in political opinion across eighteen countries, and we pinpoint several areas of research that are in need of further empirical, methodological, and theoretical inquiry.
\end{abstract}

Keywords: class, politics, identity, public opinion, preferences, attitudes.

February, 2020

Forthcoming in Annual Review of Sociology (Vol. 46, 2020)

Acknowledgements: We are extremely grateful for comments from the $A R S$ reviewer and editor, Jonas Edlund, Lane Kenworthy, Christopher Maggio, Cody Melcher, Stephen Morgan, Yerko Royas, and Liza Steele, as well as from participants at presentations at the Swedish Institute for Social Research, Stockholm University, and the University of Konstanz, especially Christian Breunig. Thanks also to Stefan Svallfors for providing the template for our figures. Arvid Lindh acknowledges financial support from the Swedish Research Council (grant no. 2015-01702) and the Swedish Research Council for Health Working Life and Welfare (grant no. 2017-00079). 


\section{Class Position and Political Opinion in Rich Democracies}

\subsection{INTRODUCTION}

Scholars and public commentators have long been interested in the question of how an individual's class position affects their political orientation. Yet because the nature of the relationship between class and politics can change as society itself transforms, scholarly perspectives on the topic have shifted quite substantially over time, and, it could be argued, even in just the last few years. Our review seeks to capture these key developments in the literature while simultaneously acknowledging the current literature's crucial continuities with the past. To do so, we draw from multiple disciplines and theoretical perspectives that appear to us to be converging on a similar set of themes. We also discuss class differences in political opinion across an array of substantive domains and national contexts.

Specifically, two interrelated themes that we highlight are (1) the increasing scope and interdependence of economic, social, and political analysis, and (2) a growing interest in understanding how class position and identity are related to social status distinctions such as race, ethnicity, and gender (Ridgeway 2014). Each of these two themes represents a different facet of multidimensional analysis. Because there are already several recently published reviews on various aspects of the class/politics relation, including on class and voting (Evans 2017), class and political engagement (Laurison 2016), class and policy responsiveness (Erikson 2015), and class and policy preferences (Manza \& Crowley 2018), our goal is to draw from these reviews (and much other research) to offer an integrative understanding of the role of class position in shaping political opinion from a broadly multidimensional perspective. We also discuss political opinion within the context of related developments covered by these reviews, such as voting behavior. 
Concretely, our review is organized into three broad issue and identity domains: the economic (Section 2), the sociocultural (Section 3), and the political (Section 4). The first domain examines the multidimensionality of class politics with respect to economic issues. For instance, there exist multiple pathways through which a desired distribution of economic resources and life chances can be achieved, even though a large and influential literature on the politics of class inequality tends to emphasize the pathway involving explicitly redistributive policies (i.e., government taxes and transfers). The second domain considers how class position relates to sociocultural issues, primarily as a way to better understand how views on sociocultural issues interact with views on economic issues related to class position. Here we also explore the ties between class politics and so-called identity politics, which are concerned with equality among social status groups (Crenshaw 1991). The third domain concerns tensions surrounding the legitimacy of democratic governance. These tensions may arise from a perceived lack of government responsiveness to the economic concerns of working- and lower-middle-class groups, and may also be reflected in populist movements.

Two other key features of our discussion bear emphasis up front. First, to highlight continuities with past schools of research, we approach these issue and identity domains from two levels of analysis: the micro/individual level, or what individuals "demand" from government, and the macro/contextual level, or what political institutions - such as political parties, existing policy structures, and even the media - "supply" in terms of both new ideas and binding constraints (Sartori 1969; Campbell 2012; Mudge \& Chen 2014). As a shorthand, we refer to these different levels of analysis as demand-side and supply-side perspectives, respectively. Second, and related, methodological concerns are central to our arguments, as we think they have become unacknowledged determinants of some of the key (and potentially misleading) conclusions in this area of research. For instance, the proliferation of micro-level survey data 
(e.g., via online platforms) can lead to one-sided research that ignores supply-side factors, which often require data over long periods of time and/or deep qualitative analysis to be uncovered. When we discuss a few pieces of research in unusual detail, we do so mainly to illustrate this broader methodological point.

Finally, for the purposes of this review, we largely sidestep ongoing debates over different theories and definitions of class (Wright 2005, Lareau \& Conley 2008), especially since there are recent thoughtful reviews that focus on these debates through the lens of public opinion research (Manza \& Crowley 2018). That is, our main priority is to better understand how and when class matters rather than to debate whether it is worthwhile to examine at all. Furthermore, we concentrate on topics that are relevant to most advanced Western democracies because we have limited space to delve into the idiosyncrasies of individual countries. To illustrate our arguments, we include empirical data on eighteen countries across several regions of the world pertaining to citizens' opinions regarding the welfare state, immigration, and government responsiveness. ${ }^{1}$ In this regard, we strive to integrate and extend analysis of these topics in the U.S., the primary focus of most of the recent reviews cited above, with their analysis in other high-income countries.

\subsection{THE ECONOMIC DOMAIN}

Political research on class has traditionally centered on economic issues. In contemporary research, two main analytical approaches can be distinguished. One approach sees the single aim of securing economic redistribution as the objective of class struggle. The prevailing theory of

\footnotetext{
${ }^{1}$ We use various years of data from the International Social Survey Program. The countries included are Australia (AU), Belgium (BE), Canada (CA), Denmark (DK), Finland (FI), France (FR), Germany (DE), Great Britain (GB), Ireland (IE), Japan (JP), Netherlands (NL), New Zealand (NZ), Norway (NO), South Korea (KR), Spain (ES), Sweden (SE), Switzerland (CH), and the United States (US).
} 
redistributive preferences in the United States over the last several decades, the median voter model, is probably the most prominent example of this approach (Meltzer \& Richard 1981). The other focuses on how the character and magnitude of class conflict vary across different domains of the welfare state, which have both direct and indirect effects on economic well-being (Korpi \& Palme 2003; Beramendi et al. 2015).

The second approach is most relevant to our review because of its scope, encompassing elements of the first approach. A fundamental distinction made within this approach is among the redistributive, social insurance, and social service functions of the welfare state (Baldwin 1990; Moene \& Wallerstein 2001). Redistribution involves explicit shifting of resources and life chances downward in the class hierarchy through a combination of extensive taxation, income transfers, and social assistance. By contrast, social insurance and social services primarily protect individuals in both the working and the middle classes against material insecurities brought about by ill health, job loss, family care, and old age. Expectations of conflict stemming from opposing economic interests among classes within the redistributive dimension are quite straightforward and well developed (Korpi 1983; Huber \& Stephens 2001). However, expectations of class conflict are less clear in the social insurance and social service arenas, in particular where the middle classes are invested in the public provision of health care, pensions, child care, and so forth (Korpi \& Palme 1998; Rothstein 1998).

In the following, we draw on data from the 2016 Role of Government module of the International Social Survey Programme (ISSP) for 18 countries to illustrate class differences in views of these policy domains, and we also examine potential explanations of these views. For the empirical analyses, we build on the sociological tradition that treats classes as structural positions in labor markets and workplaces, positions that individuals are aligned with based on 
their occupation and employment relationship (i.e., employee, self-employed, or employer). ${ }^{2}$ Recent political research using this approach distinguishes between classes hierarchically and horizontally. Consequently, we separate manual workers (the old working class) from service workers (the new working class) and managers and business professionals (the old middle class) from sociocultural professionals (the new middle class). ${ }^{3}$ Because individuals in working-class occupations can obtain relatively high incomes, and individuals in middle-class occupations can be financially insecure and/or unrepresentative of the economic elites in contemporary societies with high levels of income inequality, at times we refer to the broad lower and middle parts of the income distribution as the working- and lower-middle classes.

Figure 1 shows support for redistribution by class and country. We constructed an index (scale $0-100$ ) that adds together two separate items on whether it is the government's responsibility to "reduce differences in incomes between rich and poor" and "provide a job for everyone who wants one" (see Supplemental Material B for further information.) The figure displays predicted values for each class segment, by country. Predicted values are based on country-specific (OLS) regression models with controls for gender, age, sector of employment (private/public), geographical location (urban/rural), and religiosity. In all 18 countries, manual workers express stronger redistributive preferences than managers and business professionals.

\footnotetext{
${ }^{2}$ It is also common to measure class with income and/or education (which both correlate with occupation). These different measures provide a relatively similar descriptive picture of the main political divisions between the "lower" and "higher" classes. Still, there are nuanced differences in results across measures. For example, occupation and/or income are typically stronger predictors of views on economic issues, whereas education often performs better in accounting for sociocultural views (Evans \& Tilley 2017; Manza \& Crowley 2018).

${ }^{3}$ Examples of occupations in each group are (in brackets): Managers and business professionals (managers, accountants, administrators); Sociocultural professionals (teachers, nurses, social workers); Manual workers (lorry drivers, machine operators, mechanics); Service workers (cleaners, health care assistants, shop assistants). For further information, see Supplemental Material A; Hout et al. 1995; Kriesi 1998; Oesch 2008; Evans \& Tilley 2017. Other researchers similarly examine horizontal distinctions but within income and education groups (recent examples include Kitschelt \& Rehm 2019; Piketty 2020).
} 
Figure 1. Support for economic redistribution. Numbers are predicted values for each class segment based on country-specific OLS regressions. Higher scores indicate more support.

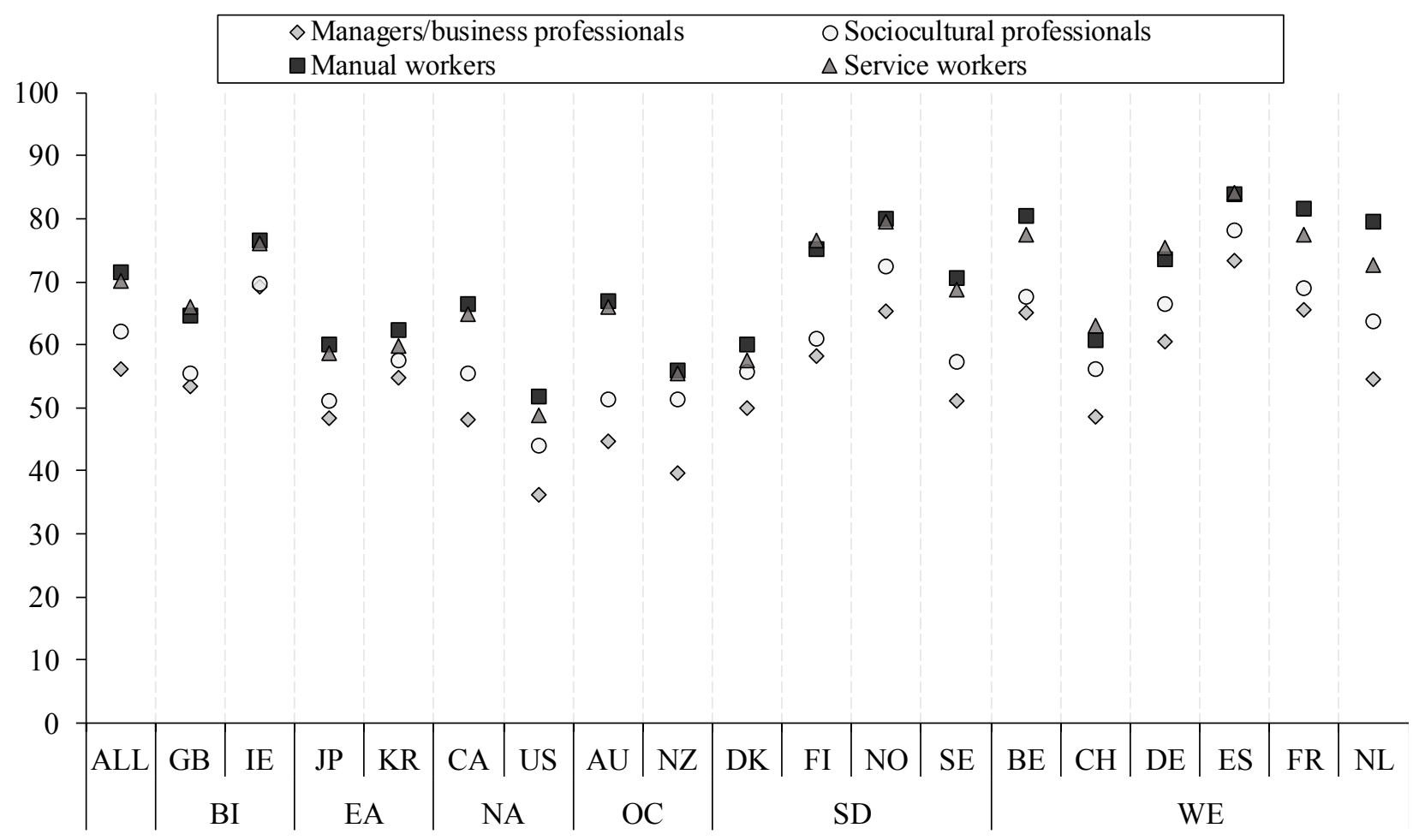

Source: International Social Survey Programme Role of Government 2016 (ISSP 2018). Data for CA, IE and NL is from 2006.

Notes: Additive index with scale $0-100$. These are predicted values based on country-specific linear OLS regressions with controls for gender, age, geographical location (urban/rural), sector of employment (private/public), and religiosity. The predictions are for a middle-aged woman working in the private sector, that is non-religious and living in a small town. Based on multiple imputation by chained equations (20 datasets for each country). See Supplemental Materials A-C for further information. 
On average, this difference is about 15 points (the individual-level standard deviation of the index is about 27 points). Service workers express similar attitudes as manual workers in all countries except the Netherlands. The relative positioning of sociocultural professionals varies: in some countries, they are about as supportive of redistribution as workers are, whereas in other countries their support is more similar to that of managers and business professionals.

In terms of explanations of these views, we consider four types: objective economic self-interest, subjective class identity, deviations from narrow economic self-interest stemming from other-regarding attitudes or misinformation, and contextual influences. First, and most obviously, a large body of research provides evidence that the microlevel link between class position and redistributive preferences is anchored in the economic risks and rewards of workers, such as their wages/income and employment security (Brooks \& Svallfors 2010; Rehm et al. 2012). Wealth as a distinct factor may matter as well, but unfortunately it is rarely measured in the standard surveys of the general population that are used in this research, and, when it is, the sample sizes of individuals at the very top of the distribution are small and unreliable. However, the few studies that have carefully surveyed wealthy citizens suggest that they are more opposed to redistribution than the average manager and business professional whose attitudes appear in Figure 1 (Page et al. 2013; Arndt 2019).

Second, the potential significance of subjective class identity as an explanation of redistributive preferences has received some attention in prior research, which distinguishes between the class identity individuals claim for themselves and the class position researchers assign to them. While there is a strong correlation between objective and subjective indicators, there is far from a perfect overlap. For instance, class identity is not only shaped by an invidual's current structural position but also by his or her class origin (Curtis 2016). However, some empirical studies claim that class identity is insignificant when controlling for additional factors 
in the United States (Sosnaud et al. 2013), whereas in other countries (e.g., Scandanavian), subjective class identity interacts with an individual's objective class in shaping preferences (Edlund 2007). Related to this, social mobility has been linked to redistributive preferences as well (Jaime-Castillo \& Marqués-Perales 2019).

Third, there is growing scholarly interest in the extent to which people's notions of fairness and equity towards others or their lack of policy-relevant information might account for their failure to act in line with their narrow economic class interests vis-a-vis redistributive policies. ${ }^{4}$ (We consider the role of sociocultural factors in explaining this outcome in the next section.) For example, there is a literature in the U.S. arguing that groups with below-mean incomes may support policies that favor the rich based on their lack of information about the scale of inequality and/or the benefits of taxing the rich (e.g., Bartels 2008; Kuziemko et al. 2015). Along the same lines, recent research documents misperceptions of median constituent preferences by elected officials, who perceive such preferences to be more conservative than they actually are (Broockman \& Skovron 2018). A separate literature places emphasis on altruism and other-regarding motives as central to support for economic redistribution, particularly among high-income individuals, for whom narrow economic self-interest would lead to opposition (Lupu \& Pontusson 2011; Gilens \& Thal 2018; Dimick et al. 2018). The interpersonal and caring logic of sociocultural professions also trigger or reflect (based on selection) such socialpsychological orientations, which partly explain why this group leans in a more leftist direction than other segments of the middle class (Hout et al. 1995; Kriesi 1998; Kitschelt \& Rehm 2014).

\footnotetext{
${ }^{4}$ This research is related to longstanding debates about the general importance of self-interest compared to other factors in shaping political opinions (cf., Sears \& Funk 1990; Weeden \& Kurzban 2014).
} 
Fourth, contextual economic factors can be of importance in explaining redistributive attitudes. The "death of class" thesis that was central to class debates in the nineties contends that the political significance of class is declining in postindustrial societies, as economic growth and affluence, combined with the growing salience of "postmaterial" values, have eroded the foundations of class politics (Inglehart 1990; Clark \& Lipset 1991; Clark et al. 1993). According to this perspective, social class has simply ceased to matter in people's lives: "Though economic factors tend to play a dominant role in the early stages of industrial society, in advanced industrial society their relative importance diminishes; and self-expression, 'belonging' and the quality of the physical and social environment become increasingly important" (Inglehart \& Rabier 1986:456).

Yet the empirical evidence to support the argument that class divisions in redistributive preferences erode in tandem with economic development is weak. In particular, non-deterministic versions of this thesis hypothesized that class conflict would mainly decline in societies characterized by diminishing material inequality (Clark et al. 1993; see also Clark \& Lipset 1991). But this prediction has not been borne out, both because material inequality has increased in many affluent nations (unexpectedly), and because the cleavage in redistributive preferences between the working and middle classes persists at non-trivial levels (Evans \& Tilley 2017; Wodtke 2017; Figure 1), and tends if anything to be greater in countries with less economic inequality. Drawing on the median voter model, political economists suggest this is because of a decline in polarization among income groups as the share of the population with below-mean incomes in unequal societies increases (think of the "ninety-nine percent"; see Finseraas 2009; Lupu \& Pontusson 2011; Schmidt-Catran 2014). However, other scholars theorize that the magnitude of redistributive class conflict might reflect (or is endogenous to) the character of the welfare state and associated political institutions because of the informational and ideological 
messages they convey (Svallfors 2006; Brady \& Bostic 2015; Edlund \& Lindh 2015; Fernández \& Jaime-Castillo 2017). We return to this issue in Section 4 on political feedback.

Turning now to other economic policy domains besides explicit government redistribution, in the same survey battery of the 2016 ISSP as the items used for Figure 1, there are questions that gauge preferences regarding social insurance that protect against insecurities related to sickness and old age. Figure 2 shows that the level of support is high in all classes and countries, including in the United States. These patterns lend credence to the theoretical argument that the popular legitimacy of an ambitious welfare state rests on universal programs that cover the needs of both workers and the middle class (Korpi \& Palme 1998; Rothstein 1998). These findings also fit well with research demonstrating that there is super-majority support in the U.S. for many universalistic government policies that are based on contributions from labor earnings, and which only secondarily, and perhaps invisibly to the public, aim to reduce inequality through redistributive mechanisms (Howard 1997; Kenworthy 2014).

Although the survey questions needed to illustrate our next point are not available from the ISSP, a promising development in the literature, we believe, is that scholars have moved beyond an exclusive focus on "compensation" policies that equalize post-tax and transfer economic outcomes (i.e., through redistributive and social insurance mechanisms) to consider "investment" policies that promote equality of economic opportunity over the life-course through early childhood development, child care, education, and training policies (Morel et al. 2012; Hemerijck 2013; McCall \& Kenworthy 2009). It is argued that core social constituencies of contemporary European welfare states - most notably sociocultural professionals - increasingly favor social investment policies over compensation policies, even though these policies tend to have high support among working-class constituencies as well (Busemeyer 2015; Häusermann \& Kriesi 2015). 
Figure 2. Support for universal social protection. Numbers are predicted values for each class segment based on country-specific OLS regressions. Higher scores indicate more support.

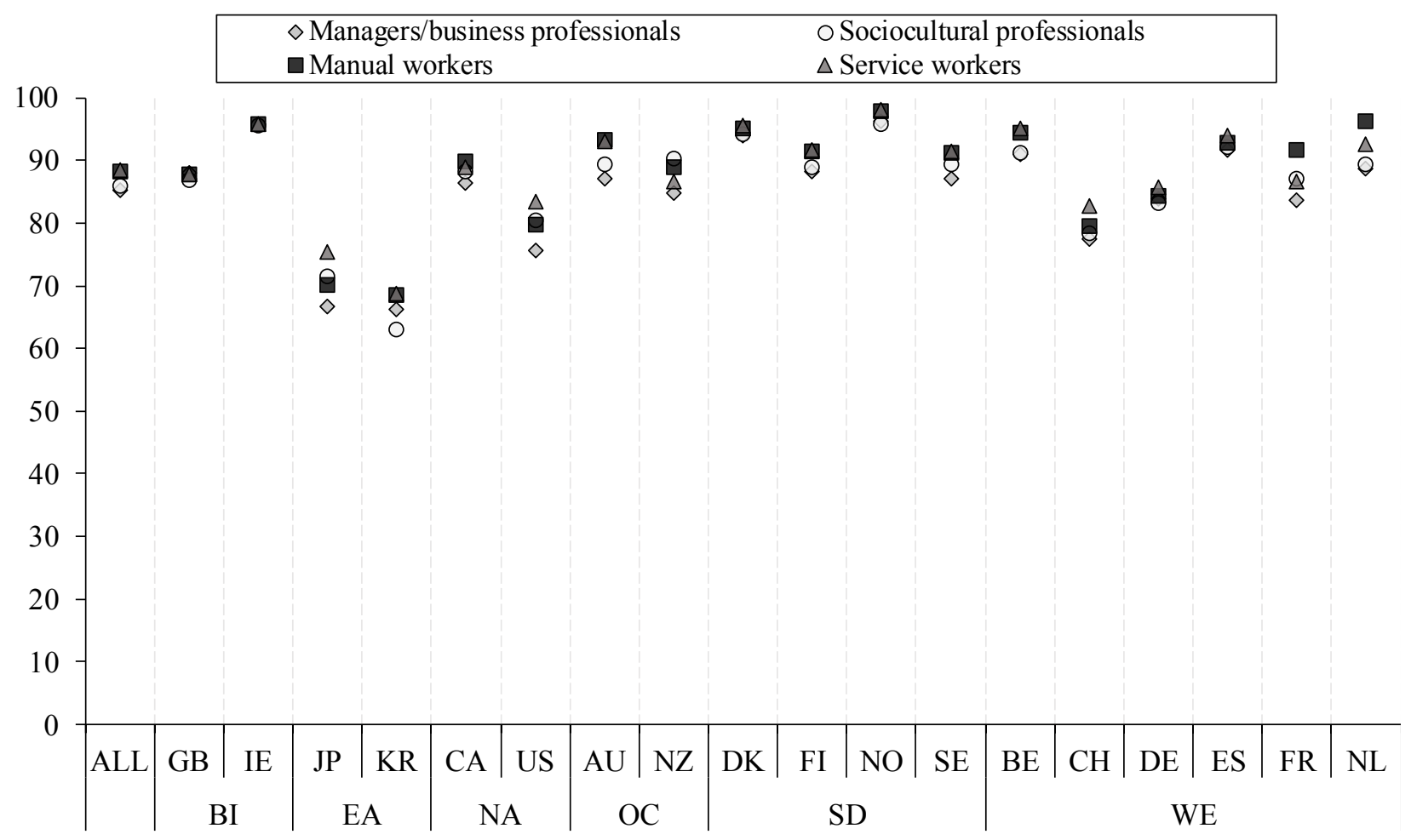

Source: International Social Survey Programme Role of Government 2016 (ISSP 2018). Data for CA, IE and NL is from 2006.

Notes: Additive index with scale $0-100$. These are predicted values based on country-specific linear OLS regressions with controls for gender, age, geographical location (urban/rural), sector of employment (private/public), and religiosity. The predictions are for a middle-aged woman working in the private sector, that is non-religious and living in a small town. Based on multiple imputation by chained equations (20 datasets for each country). See Supplemental Materials A-C for further information. 
Finally, despite the fact that labor earnings comprise the overwhelming share of individual and household income, there are only a few studies that focus on preferences for economic policies that directly address pay disparities in the market. For instance, regulatory policies such as the minimum wage generate significant support in the U.S. (Bartels 2008; McCall \& Kenworthy 2009), as do employer-provided benefits and procedures to augment worker voice (Kochan et al. 2019). A majority of Americans also believes that major companies should cut executive pay and raise unskilled worker pay, which exceeds the share of Americans that favors conventional government redistribution as shown in Figure 1 (McCall et al. 2017). Although these views decline with income, Americans in quite large numbers distrust major companies, almost to the degree that they distrust the government, which is a lot (Lindh \& McCall 2019). As a whole, these findings are inconsistent with key tenets of American free market ideology and point to the potential popularity of a market equality agenda.

\subsection{THE SOCIOCULTURAL DOMAIN}

One of the reasons frequently given for political behavior that seems to deviate from narrow class interests is that sociocultural issues have become more salient than economic issues in shaping political decisions. Since electoral behavior is a function of both demand-side and supply-side factors, sociocultural attitudes might not have consequences in the formal political sphere (i.e., on the demand side) if parties as supply-side actors compete on the nonsociocultural plane alone. However, issues concerning gender relations, race and ethnicity, environmentalism, and sexuality became more outwardly salient and partisan in the wake of the new social movements of the 1960s and 1970s, as did immigration with its expansion at roughly the same time (Inglehart 1990; Kitschelt \& McGann 1995). While the sociocultural and economic dimensions have long been 
considered the core axes of a two-dimensional space of political ideology, it is only recently that debates over the relative importance of each dimension have come to dominate political analysis across high-income countries.

Because research on these topics is still unsettled, our discussion of this burgeoning literature will inevitably be inconclusive. We begin by describing empirical findings in the literature on class differences in sociocultural views, which is followed by our own illustration from the ISSP data on views of immigration, given its current political salience across our sample of countries (and given our limited space). We then seek to complicate the identification of immigration and other putatively sociocultural issues as strictly noneconomic in nature by discussing alternative ways of conceptualizing, measuring, and interpreting preferences regarding both economic and sociocultural issues and their interdependence. Here we zero in on the U.S. case, both because of its long history of research on the politics of race, ethnicity, and immigration, and because of instructive methodological debates that have taken place over the past couple of years in the literature on the Trump vote (and by analogy the literature on support for populist parties and candidates in other countries).

Beginning with empirical patterns, Seymour Lipset's (1960) early work on working-class authoritarianism was among the first to document that class-related factors shape both economic and sociocultural attitudes. Whereas workers tend to be more liberal than the middle classes on (primarily redistributive) economic issues, they tend to be more socially conservative compared to the middle class on many sociocultural issues (Houtman 2003; Svallfors 2006; Gilens 2012). ${ }^{5}$ Such relative class differences have persisted even as

\footnotetext{
${ }^{5}$ Debates are ongoing about the specific mechanisms underlying these patterns. The social capital and socialization aspects of higher education seem to matter, but less clear is the extent to which the economic consequences of lower education also matter (Houtman 2003; Stubager 2008; Mendelberg et al. 2017). Employment conditions, work experiences and skills play some role (Bengtsson et al. 2013; Kitschelt \&
} 
modernization approaches have accurately predicted an absolute increase in social liberalism over time in tandem with economic development, a state of affairs that owes to both generational replacement and changing views over the life course (Inglehart 1990; Norris \& Inglehart 2019; Adamczyk \& Liao 2019). ${ }^{6}$

Immigration is one sociocultural issue that is currently politically salient in most advanced capitalist democracies and that exhibits class differences in political opinion. Liesbet Hooghe and Gary Marks (2018) place immigration at the heart of an emerging political cleavage that "has as its focal point the defense of national political, social and economic ways of life against external actors who penetrate the state by migration, exchanging goods or exerting rule" (2018:110; see also Kriesi et al. 2012; Rodrik 2018). Public atittudes toward immigration have been the focus of a large and contentious body of research (Kymlicka \& Banting 2006; Ceobanu \& Escandell 2010; Fussell 2014), and anti-immigration sentiments are a common denominator of supporters of radical right parties (Rydgren 2007; Oesch 2008). Such sentiments are also linked to scepticism of European integration (Hobolt \& de Vries 2016), support for Brexit (Hobolt 2016), the Trump victory (Sides et al. 2018), and an embrace of "welfare chauvinism," which articulates a view of immigrants and other minorities as undeserving of social citizenship rights and welfare benefits (Reeskens \& Van Oorschot 2012).

Using ISSP data from 2013, Figure 3 illustrates class divisions in attitudes toward immigration. With the exception of East Asian countries, class divisions are apparent in all countries, with workers expressing more negative views than the middle classes, on average. In

Rehm 2014; Pardos-Prado \& Xena 2019), as do shifts in relative social status distinctions among class groups (Chan \& Goldthorpe 2007; Gidron \& Hall 2017), and class background (Langsæther et al. 2019). ${ }^{6}$ Views about sexuality and LGBTQ individuals, for example, have become more tolerant in recent decades (Adamczyk \& Liao 2019), even as working-class individuals tend toward greater traditionalism relative to middle-class individuals (e.g., Andersen \& Fetner 2008). 
addition, in many countries, sociocultural professionals are somewhat more positive than managers and business professionals, a finding that fits well with recent research on this group's political distinctiveness (Kitschelt \& Rehm 2014; Häusermann \& Kriesi 2015; Oesch \& Rennwald 2018). Still, we note that support for immigration even among workers registers around the mid-point of the scale on average across countries, and is above this level in the U.S. Moreover, across countries, views toward immigration have generally been stable in recent years (Bohman \& Hjerm 2016).

Placed alongside the data from the previous section on views toward economic policies, these attitudinal patterns speak to the potential complexity of establishing durable class coalitions in advanced capitalist democracies. Most notably, while both workers and sociocultural professionals might support egalitarian economic policies, they do not necessarily agree on sociocultural issues. This potential clash in views has been dubbed "the progressive's dilemma," in which the rising diversity of contemporary western societies might reduce the solidarity needed to support a universalistic social safety net (Alesina \& Glaeser 2004; Van Oorschot 2006; Putnam 2007). Evidence contrary to this thesis, however, is provided in several rigorous crossnational studies (Kesler \& Bloemraad 2010; Brady \& Finnegan 2014; Steele 2016). Beyond different levels of support, it is also possible that working and middle classes will simply place different weights on the economic and sociocultural domains (Klar 2014), may favor different policies within each domain (Traber et al. 2019), and may be targeted differentially by party platforms and candidate rhetoric that strategically emphasize some issues (e.g. fear of immigrants and other racial cues) more than others to mobilize adherents (Hutchings \& Valentino 2004; Druckman et al. 2013). These propositions all point the literature in new directions that merit further study. 
Figure 3. Views on immigration. Numbers are predicted values for each class segment based on country-specific OLS regressions. Higher scores indicate more liberal views.

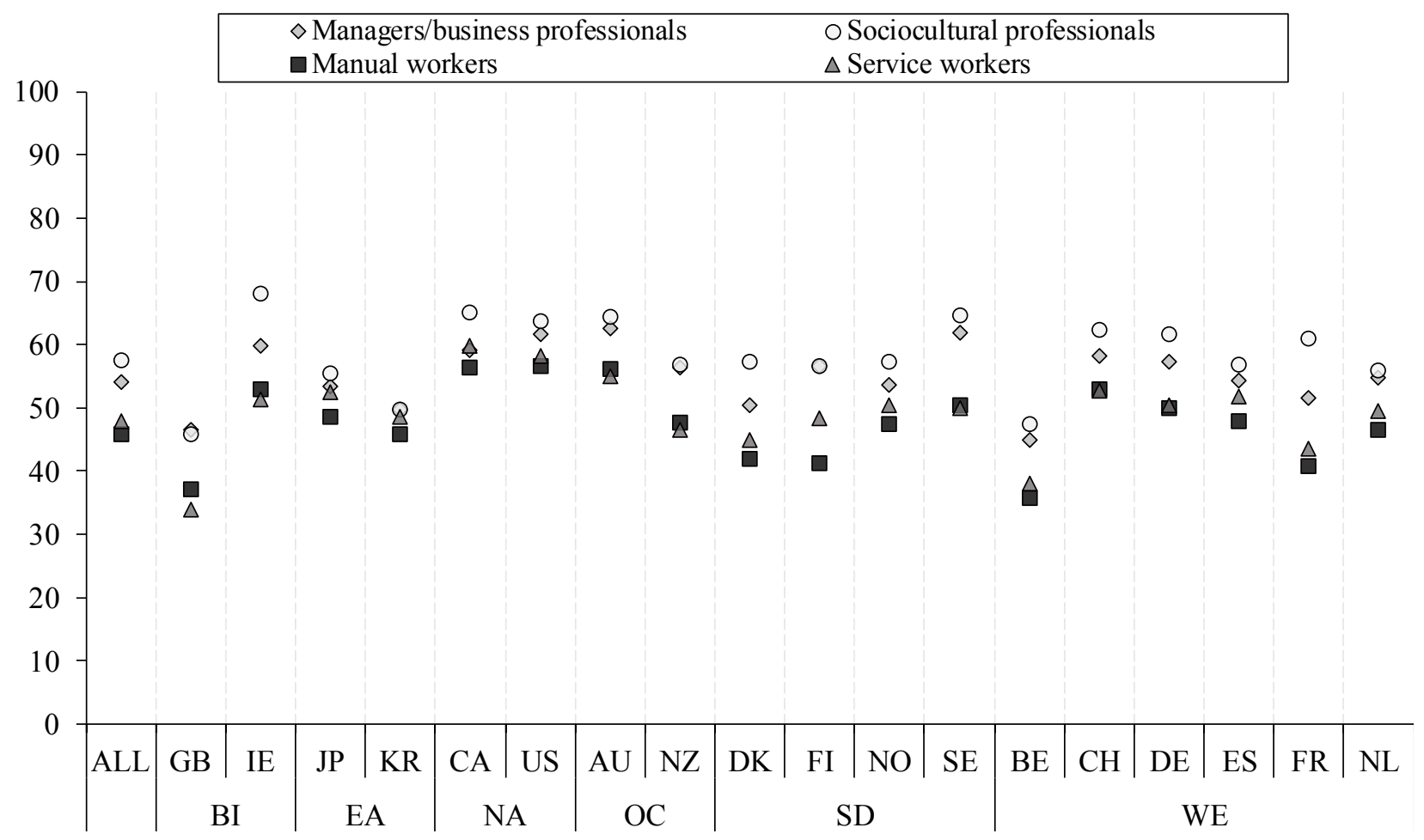

Source: International Social Survey Programme National Identity 2013 (ISSP 2015). Data for AU, CA, NL and NZ is from 2003.

Notes: Additive index with scale $0-100$. These are predicted values based on country-specific linear OLS regressions with controls for gender, age, geographical location (urban/rural), sector of employment (private/public), and religiosity. The predictions are for a middle-aged woman working in the private sector, that is non-religious and living in a small town. Based on multiple imputation by chained equations (20 datasets for each country). See Supplemental Materials A-C for further information. 
Given these complexities, we now transition to a discussion of how to conceptualize, measure, and interpret class differences in views of sociocultural issues writ large, particularly when those views may also be influenced by economic concerns. We start by acknowledging the fact that a major line of research, especially in the United States, has long maintained that divides between racial, ethnic, immigrant, and gender groups are connected to struggles over the development, extension, and sustainability of the welfare state (as well as over other political issues; Hutchings \& Valentino 2004). Because the recipients of welfare state benefits are often disproportionately from groups marginalized by race/ethnicity and gender, such groups have often been labeled undeserving of welfare state benefits by dominant groups (i.e., white, native-born men and women) in struggles over taxes and resources (Quadagno 1994; Fox 2012). By contrast, welfare state policies that are more universal in coverage and that are not perceived as explicitly redistributive, such as old-age insurance, are less contentious (as illustrated in Figure 2), and the recipients are considered more deserving (Skocpol 1991; Gilens 1999; for parrallel discussions of and variations in "welfare deservingness" in a European context, see e.g., Van Oorschot 2006; Larsen \& Dejgaard 2013).

Conceptually, it is useful to connect these well-known findings in the literature to the newer body of research on the sources of right-wing partisanship and populism in both contemporary Europe and the United States, a literature that emphasizes explanations rooted in theories of social identity threat and cultural backlash among working- and lower-middle-class whites (e.g., Mutz 2018; Norris \& Inglehart 2019). While the exact mechanisms may differ across time and place (e.g., reactions to Obama versus Trump; see Sides et al. 2018), according to such theories, privileged groups perceive themselves as having lost status relative to immigrants, women, LGBTQ individuals, and/or people of color, and see members of these groups as unfairly ascendant as a result of the egalitarian social policy agenda of left-liberal parties, which are ipso 
facto failing to defend the traditional values of the dominant culture (Lilla 2018; Hochschild 2016). Several other studies adopted explanatory frameworks in which identity concerns assumed primary significance over economic interests, or concerns about any policy-specific issues at all, in explaining contemporary political patterns (e.g., Cramer 2016; Achen \& Bartels 2016; Iyengar et al. 2019).

We believe these studies have three main shortcomings if one is trying to parse how sociocultural concerns affect the relationship between class position and political opinion. The first is that it is unclear a priori whether measures of status threat and cultural backlash reflect concerns about social status, economic status, or both, or whether social status and economic hardship are measured with equal reliability and validity, such that they can be fairly compared in a statistical analysis. ${ }^{7}$ Even in qualitative research, authors such as Hochschild (2016:137) emphasize resentment caused by minorities "cutting in line" ahead of struggling whites in Louisiana to explain the latter's support for the anti-government Tea Party. Analogously, Katherine Cramer (2016) pinpoints a "rural consciousness" that pits rural whites in Wisconsin against political elites in Madison and minorities in Milwaukee (both urban areas). The unidimensional politics of identity - whether racial, cultural, and/or geographical in origin - take center stage, despite the fact that both Hochschild's and Cramer's compelling ethnographic accounts are replete with evidence of the subjects' outrage and despair over the concentration of economic power and resources in the hands of economic and political elites. ${ }^{8}$

\footnotetext{
7 See especially Morgan's (2018) re-analysis of Mutz's (2018) data, Morgan \& Lee (2019), and Green \& McElwee (2019), who conclude that "both racial attitudes and economic conditions are significantly associated with voting behavior in 2016... [yet the] findings make clear the difficulty of directly...attributing Donald Trump's election to one as opposed to the other" (Green \& McElwee 2019:360). For similar arguments in Europe, see Naumann \& Stoetzer (2018), Burgoon et al. (2019). ${ }^{8}$ The "deep story" of "cutting in line" by undeserving minorities is unspoken by Hochschild's subjects and is an interpretation of the data (Hochschild 2016:135-37). Cramer makes the argument that identities, not positions on economic issues, guide political behavior (Cramer 2016:167). Similarly, our reading of
} 
But placing questions of measurement and interpretation to the side for the moment, we are left with a second problem, which is how exactly to explain resentments rooted in social identity rather than economic interests, and whether there are conditions under which their salience wanes or their valence shifts (McDermott et al. 2019). While political preferences are not fully elastic, neither are they hard wired to group identities, something that some of the most influential of the original studies on class mobilization (Lipset \& Rokkan 1967; Korpi 1983; Przeworski \& Sprague 1986) and the relationship between race and the welfare state (Quadagno 1994; Gilens 1999) underscore. ${ }^{9}$ Related, these earlier studies did not take for granted that the left-liberal party is a transparently obvious choice even for working-class individuals, both because the left-liberal party can be ineffective in consciously mobilizing working- and lowermiddle-class constituencies and because it can outright ignore what it considers, sometimes erroneously, unpopular causes of minority groups (unpopular with either dominant groups or the political donor class; see e.g. Frymer 1999; Eidlin 2016; Piston 2018). ${ }^{10}$ Again, Cramer's nuanced analysis at times recognizes this point (Cramer 2016:219), but it is displaced by the master explanatory concept of rural identity.

Mutz (2018) is congruent with that of Morgan (2018:fn. 2), who argues that Mutz deemphasizes the distinction between economic hardship and status threat "because status threat is a unifying narrative," rather than a separate analytical dimension (Morgan 2018:fn. 2).

9 "Class, religion, ethnicity, race, or nation do not happen spontaneously as reflections of objective conditions in the psyches of individuals. [They are] ... continuously transformed ... as a result of conflicts in the course of which political parties, schools, unions, churches, newspapers, armies, and corporations strive to impose a particular form of organization upon society (Przeworski \& Sprague 1986:7-8)." We should add the criminal justice system to this list in the U.S. case (Weaver and Lerman 2010). The debate over changes in partisan identification in the U.S. offers another instructive example: partisan polarization is increasingly construed as an in-group versus out-group identity dynamic (Iyengar et al. 2019), whereas others have shown that opposition to all flavors of partisanship has grown and is rooted in a general distrust of politics (Klar et al. 2018).

${ }^{10}$ By contrast, an example of conservative party mobilization of non-college-educated white men and women would be Donald Trump's use of a distinct fusion of class, racial/ethnic, and gender/sexual interests and identities (Gest 2016; McCall \& Orloff 2017; Green \& McElwee 2019). 
A third and related shortcoming, we suggest, is that the studies we discuss here overlook the role of comparative and contextual factors because they use data on individual attitudes and behavioural outcomes that are easily accessible in microlevel surveys or qualitative interviews. Multilevel studies using microdata but also affixing contextual information offer a counterweight. Such comparative studies suggest that aggregate sociocultural factors (e.g. the share of the immigrant and/or ethno-racial population), aggregate economic factors (e.g. the level of unemployment and/or economic inequality), and individual economic factors (e.g., exposure to or protection from job competition) all interact in heterogeneous ways to forge conservative or leftist positions among different class segments (Schmidt-Catran \& Spies 2016; Rueda \& Stegmueller 2019; Dal Bó et al. 2019; see Quillian 1995 for an early example, and Gay 2006 for an application to racial groups). For instance, an emerging finding in this literature is that it is high-income groups that reduce their support for redistribution in contexts of high ethnic heterogeneity and/or immigration (Rueda \& Stegmueller 2019; Naumann \& Stoetzer 2018). In the qualitative literature, an equivalent comparative approach is exemplified by Michele Lamont's (2000) analysis of societal-level differences between American and French working-class men's political ideologies, which are also integrally layered by racial and gender ideologies. We next provide a more thorough discussion of these contextual and supply-side dynamics.

\subsection{THE POLITICAL DOMAIN}

We have referred throughout this review to supply-side (or institutional) explanations of political opinions. There is a quite vast - mostly U.S. - literature that studies the extent to which policy making corresponds to public opinion (Erikson et al. 2002; Shapiro 2011; Canes-Wrone 2015). Typically rooted in some version of a median voter model, this literature on policy responsiveness has traditionally examined average or majority opinion. However, research on the 
political causes and consequences of rising economic inequality is flourishing, with a fundamental question being whether economic inequality is associated with inequality in political representation (Bartels 2008; Erikson 2015; Laurison 2016). Representational inequality can in turn generate class differences in political behavior, including differences in the likelihood of participating at all in the electoral process or of resorting to protest (Solt 2008; Weaver and Lerman 2010; Hooker 2016; Evans \& Tilley 2017; Green \& McElwee 2019; Schäfer \& Schwander 2019). Thus in this section we also discuss the behavioral consequences (e.g., voting or non-voting) of class differences in views about the political system.

Martin Gilens (2012) provides the most thorough documentation to date of the relationship between income, policy preferences, and policy decisions, finding that actual policy supported by both Democrats and Republicans responds mainly to the preferences of affluent citizens in those instances in which preferences diverge by class. Gilens explains this result as flowing from the outsized role of economic power in American political institutions and not from voter misinformation (see also Page \& Gilens 2017). Others, by contrast, uphold the demand-side perspective and emphasize deep-seated individual differences in political engagement and political knowledge, which favor the highly-educated and well-connected (Erikson 2015; see also Laurison 2016). While Gilens's work has not gone uncontested and continues to be refined and revised by other scholars of American politics (e.g., Enns 2015; Lax et al. 2019), it has substantially expanded the purview of research on political representation, and there are recent European studies that similarly reveal less political influence among the working and lowermiddle classes than among the rich (Elsässer et al. 2018; Schakel 2019).

At the same time, there is an established literature exploring perceptions of something akin to government responsiveness to the will of the people - coined external political efficacy (e.g., Soss 1999) - with the role of class in structuring such perceptions receiving some 
attention as well (e.g., Morgan \& Lee 2017). The ISSP examines these perceptions by soliciting responses to the statements "people like me don't have any say about what the government does" and "I don't think the government cares much what people like me think," which are shown in Figure 4 using data from 2014. In nearly all countries, workers express a weaker sense of efficacy than members of the middle classes do, including sociocultural professionals. Indeed, according to this measure, in most countries, the average worker hardly feels efficacious at all.

A sense of government unresponsiveness might be a gateway to populism among working- and lower-middle-class groups. Populism is a contested concept that is used with different meanings in both the public sphere and within academia (Mudde 2004). Perhaps surprisingly, scholars have only recently begun to explore the demand-side of populism from the perspective of public opinion (e.g., Akkerman et al. 2014). In this emerging literature, populism is typically defined as a set of norms advocating for the rule of the people against corrupt elites (Mudde 2004; Mudde \& Rovira Kaltwasser 2018). Populism is cast as a "thin-centered" ideology that has "a limited programmatic scope" and that "almost always appears attached to other ideological elements, which are crucial for the promotion of political projects that are appealing to a broader public" (Mudde \& Rovira Kaltwasser 2018: 1669).

An advantage of this definition is that it does not equate populism with nativism, authoritarianism, and/or social conservatism but instead considers it an empirical question whether views about populist governance correlate with other political views. While populism is often described as a backlash against political elites, there is reason to believe that populist resentment is also directed at economic elites or motivated by economic insecurities, which can be diverted into causes on the left as well as on the right (Oliver \& Rahn 2016; Bonikowski \& 
Figure 4. Perceptions of government responsiveness. Numbers are predicted values for each class segment based on country-specific OLS regressions. Higher scores indicate more responsiveness.

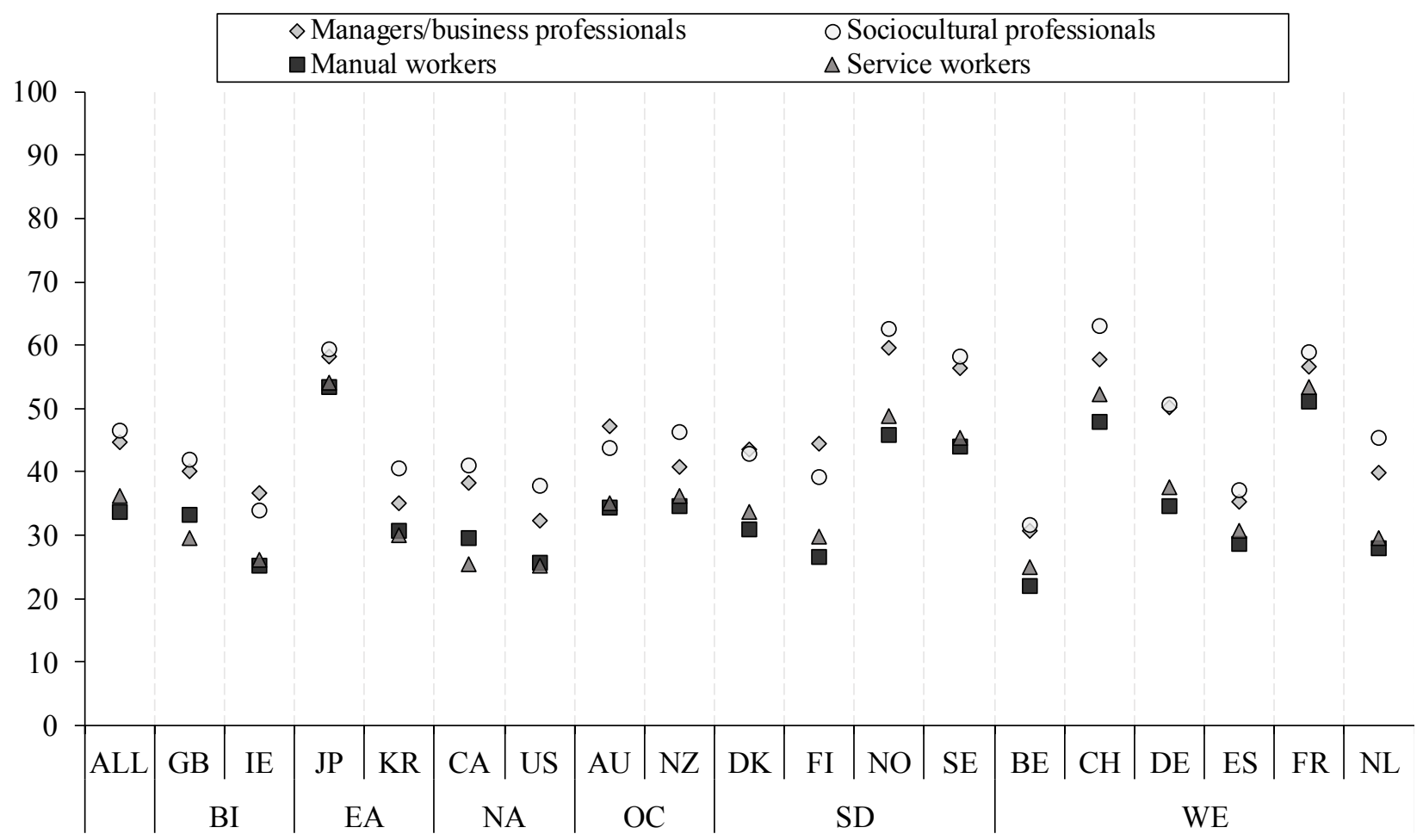

Source: International Social Survey Programme Citizenship 2014 (ISSP 2016). Data for CA, IE, and NZ is from 2004.

Notes: Additive index with scale $0-100$. These are predicted values based on country-specific linear OLS regressions with controls for gender, age, geographical location (urban/rural), sector of employment (private/public), and religiosity. The predictions are for a middle-aged woman working in the private sector, that is non-religious and living in a small town. Based on multiple imputation by chained equations (20 datasets for each country). See Supplemental Materials A-C for further information. 
Gidron 2016; Mudde \& Rovira Kaltwasser 2018; Rooduijn 2019). ${ }^{11}$ One indicator of this is that people who distrust government also tend to distrust market institutions (Edlund \& Lindh 2013; Lindh \& McCall 2019), with the movements of Indignados in Spain and Gilets Jaune in France offering real-world examples. In the U.S., other signs include the Occupy Wall Street movement, which cast the top one percenters in a pejorative light and built on rising resentment against the "underserving rich" since the 1990s (McCall 2016), and, as noted above, ample evidence of working and middle class dissatisfaction with economic conditions and economic elites in recent ethnographic studies (Hochschild 2016; Cramer 2016).

Although policy unresponsiveness to working- and lower-middle-class constituencies is not necessarily unique to parties of the right or the left (Gilens 2012; Newman \& Hayes 2019; cf., Lax et al. 2019), little research has investigated whether unresponsiveness can be linked to apathy and disengagement rather than to populist party support. An established tradition in political sociology of studying political parties as manufacturers of politics, attracting as well as repelling public participation, may provide insight here (Lipset \& Rokkan 1967; Sartori 1969; Mudge \& Chen 2014; Eidlin 2016). ${ }^{12}$ Instititutional theory in political science likewise claims that political preferences are not exogenously formed but rather are shaped by existing policies, which foster constituencies and trust or, alternatively, backlash and cynicism (Pierson 1993; Mettler \& Soss 2004; Campbell 2012; Michener 2018).

\footnotetext{
${ }^{11}$ Pippa Norris and Ronald Inglehart's Cultural Backlash (2019) is a recent study on populism that has received a lot of attention. In most parts of their study, political distrust is used as a "proxy" for populism. An important task for future research is to establish whether populist attitudes differ substantively from adjacent established concepts such as political efficacy and institutional trust of various kinds (Rooduijn 2019).

${ }^{12}$ As Giovanni Sartori puts it, "[i]n the perspective of political sociology, a party system is not only a response to consumer's demands, but is equally a feedback of producer's options." (1969:211).
} 
From these perspectives, declines in class voting (i.e., clear differences in voting behavior between classes) observed in many Western countries may have more to do with elite political dynamics than with the exogenous erosion of class interests and identities among individuals (Evans \& Tilley 2017; Oskarson \& Demker 2015). In the era of industrial capitalism, mainstream parties to the left explicitly defined themselves as representing the interests of the working classes (Lipset \& Rokkan 1967; Korpi 1983; Przeworski \& Sprague 1986). These parties subsequently sought backing from members of the middle class, whose share of the electorate steadily grew. Restraint in the pursuit of redistribution followed, as attention turned to social insurance, social service, and social investment policies that draw more support from the middle classes (Beramendi et al. 2015; Gingrich \& Häusermann 2015). Simultaneously, the growing salience of sociocultural issues has elevated the socially liberal profile of many left parties, which is a profile that, as discussed in Section 3, is not always a priority shared by workers.

Importantly, systematic uresponsiveness in policymaking makes public opinion research all the more vital, as it can capture non-voter and dissenting opinions that otherwise may go undetected in research on the narrower question of vote choice. Class divisions in public opinion, in other words, may not be converted into class differences in voting, which depends on the quality of the match between citizens on the demand-side and parties and allied interest and civic organizations on the supply-side (Evans \& Tilley 2017). For instance, organized interests and public education systems, which tend to have a larger political presence in more universalistic welfare states, translate and disseminate political knowledge, in particular to the working and lower-middle classes. ${ }^{13}$ The result is that these class identities are mobilized as such,

\footnotetext{
${ }^{13}$ Country-comparative studies suggest that the strength of the link between class position and political preferences differ between countries in tandem with the level of political articulation/mobilization of social class by political parties and collective actors (Svallfors 2006; Edlund \& Lindh 2015). Similarly, Didier Eribon's (2013) qualitative study suggests that the political realignment of the French working
} 
and in greater alignment with sympathetic parties, than in countries lacking such intermediaries, where candidates, parties, and private institutions and actors may fill the class-identity vacuum in any number of ways or ignore it altogether (Edlund 2007; Gingrich 2014; Edlund \& Lindh 2015; Iversen \& Soskice 2015).

In terms of systematic longitudinal evidence that can assess the degree to which class-based political opinion is reflected in or disconnected from over-time developments in class voting, there are few high-quality surveys that go further back than the eighties, which means that we have little insight into public opinion in the heyday of the democratic class struggle.

Nevertheless, studies show, perhaps surprisingly, considerable continuity and stability in class divisions in attitudes since the eighties in the United States ${ }^{14}$ (Manza \& Crowley 2018) and Sweden (Svallfors 2011), and since the sixties in the best longitudinal study to date, in Great Britain (Evans \& Tilley 2017). Each of these studies also finds more minor shifts - sometimes toward increasing class differences and sometimes toward decreasing class differences in political opinion - that in some instances seem to coincide with the political dearticulation of class undertaken by established political parties. Taken together, the implication from this literature is that party unresponsiveness to working- and lower-middle class concerns may have grown over time and contributed to declines in class voting but left less of an imprint on class divisions in political opinion. Definitive evidence of the trend in unresponsiveness and its causal relationship to political behavior and opinion, however, is lacking and a high priority for future research.

class (from the Left to the Radical Right) is tied to the depolitization of class-relevant economic issues in French politics in recent decades.

${ }^{14}$ However, there are debates over trends using other definitions of class (Weeden \& Grusky 2012). 


\subsection{CONCLUSIONS AND FUTURE RESEARCH}

At the forefront of political research today, there is clear recognition of the continued significance of class in shaping political opinion. Yet the analytical framework for understanding the role of class has expanded substantially from what was in place even a decade ago. Key elements of this framework include: (1) an expanded conceptualization of the economic and social policy space, one that reaches beyond conventional redistributive programs and incorporates popular policies to reduce market inequalities, insure against income risks, deliver needed services, and foster employment opportunities; (2) an acknowledgement of the embeddedness of class identity and interests within other relations of inequality (i.e., gender, ethnoracial, sexual, citizenship, etc.), which together shape and contort political orientations and demands; and (3) the crucial role of political elites and institutions on both the left and the right in creating and foreclosing possibilities for the democratic representation of class interests. Methodologically, we have argued that this expanded framework requires rigorous tests of multidimensional and multilevel (e.g., supply-side and demand-side) hypotheses, or modesty in drawing conclusions when unidimensional and single-level analyses are conducted, including in qualitative research.

Building on this broad, multidimensional and multilevel framework, we see two frontiers in contemporary research that incorporates a class-analytic component. The first explores the formation of coalitions, especially those that at first may appear unlikely (e.g., among those who agree on the need for greater economic equality in the abstract but disagree on specific policy goals or on some sociocultural issues). Indeed, this question is at the heart of research in political science on the coalitional theory of parties (McCarty \& Schickler 2018). It is also a longstanding concern of legal, psychological, and political research on coalitional and intersectional orientations among individuals and across social-movement and interest-group organizations (Crenshaw 1991; Gay 2006; Strolovitch 2007; Cole 2009; Craig \& Richeson 2016). 
This and other likeminded research provide illustrations and real-world examples of political cooperation and coalition, not only of political fragmentation and division, the emphasis of much contemporary research. ${ }^{15}$

A critical lesson from this latter research that we highlight in particular is the need to acknowledge, as a starting point, potential differences in priorities and objectives between groups motivated principally by economic interests, by social status inequalities, or by some combination of the two (among those on the right as well as on the left). This is what Nancy Fraser described, nearly twenty-five years ago, as the politics of redistribution and recognition (Fraser 1995; see also Kymlicka and Banting 2006). Fraser's perspective has of necessity evolved significantly from its origins - for instance, by incorporating a supply-side dimension (i.e., the politics of representation) - and it will continue to evolve, but the refusal to neglect one set of priorities (e.g., based on social status inequalities) for another (e.g., class inequalities) endures (e.g., Fraser 2009; Moran 2018). This refusal, based on both normative presuppostions and rigorous research on coalitions, stands in contrast to various unidimensional approaches that we described in this review, which foregrounded sociocultural issues, as well as to game-theoretical and political-economic approaches that may strive to reduce conflict by minimizing multidimensionality (e.g., by foregrounding economic issues, as in, for instance, Piketty 2020).

\footnotetext{
${ }^{15}$ Campaigns for economic justice that are multiracial and benefit low-income women disproportionately - such as strikes by fast food workers and the fight for a \$15 minimum wage, predictable scheduling, and paid leave campaigns in the U.S. - demonstrate that unity among different fragments of the working class is possible; moreover, such low-wage worker movements are speading around the world (Luce 2015). Other compelling examples can be found among the budding sociocultural professionals in Ruth Milkman's (2017) analysis of the overlapping circles of millennial activists in the Dreamers, Occupy Wall Street, Black Lives Matter, and campus anti-sexual assault movements. It also is important to remember that whether political polarization is as extreme among the public as it is among political elites is still under debate (Park 2017).
} 
Finally, the second frontier dovetails with the drive throughout the social sciences for greater transparency, caution, and methodological triangulation in data analysis (Gelman 2018). In our case, we are referring to the methdological demands that can be compounded when researchers are placing diverse literatures (e.g., supply-side and demand-side) and measurement constructs (e.g., social identity and class identity) into dialogue with one another, all while attempting to accurately document the tumultuous world of politics as it is occuring. Greater attention to the limitations of existing data - and the interpretations based on those data - is imperative, coupled with an effort to carefully collect new microdata, ideally benchmarked to existing datasets of the highest quality (i.e., GSS/ISSP, ANES, ESS, etc.; see Morgan \& Lee 2019). Equally valuable will be new sources of organizational and institutional data that capture the dynamics of elite electoral strategies and policymaking (e.g., Hertel-Fernandez 2019; Broockman \& Skovron 2018). While this may sound like a tall order, our review provides several examples of past as well as new research that is leading the way. 


\section{LITTERATURE CITED}

Achen CH, Bartels LM. 2016. Democracy for Realists: Why Elections Do Not Produce

Responsive Government. Princeton: Princeton University Press

Adamczyk A, Liao YC. 2019. Examining Public Opinion About LGBTQ-Related Issues in the United States and Across Multiple Nations. Annu. Rev. Sociol. 45:401-23

Akkerman A, Mudde C, Zaslove A. 2014. How populist are the people? Measuring populist attitudes in voters. Comp. Polit. Stud. 47(9):1324-53

Alesina A, Glaeser EL. 2004. Fighting poverty in the US and Europe: A World of Difference. Oxford: Oxford University Press

Andersen R, Fetner T. 2008. Economic Inequality and Intolerance: Attitudes toward Homosexuality in 35 Democracies. Am. J. Polit. Sci. 52(4):942-58

Arndt HLR 2019. Varieties of Affluence: How Political Attitudes of the Rich Are Shaped by Income or Wealth. Eur. Sociol. Rev. (published online October 11)

Baldwin P. 1990. The Politics of Social Solidarity: Class Bases of the European Welfare State, 1875-1975. Cambridge: Cambridge University Press

Bartels LM. 2008. Unequal Democracy: The Political Economy of the New Gilded Age. Princeton: Princeton University Press

Bengtsson M, Berglund T, Oskarson M. 2013. Class and ideological orientations revisited: an exploration of class-based mechanisms. Br. J. Sociol. 64(4):691-716

Beramendi P, Häusermann S, Kitschelt H, Kriesi H. 2015. The Politics of Advanced Capitalism. New York: Cambridge University Press. 
Bohman A, Hjerm M. 2016. In the wake of radical right electoral success: a cross-country comparative study of anti-immigration attitudes over time. J. Ethn. Migr. Stud. 42(11):172947

Bonikowski B, Gidron N. 2016. Multiple Traditions in Populism Research: Toward a Theoretical Synthesis. APSA Comp. Polit. Newsl. 26(12):7-14

Brady D, Bostic A. 2015. Paradoxes of Social Policy: Welfare Transfers, Relative Poverty, and Redistribution Preferences. Am. Sociol. Rev. 80(2):268-98

Brady D, Finnigan R. 2014. Does Immigration Undermine Public Support for Social Policy? Am. Sociol. Rev. 79(1):17-42

Broockman DE, Skovron C. 2018. Bias in perceptions of public opinion among political elites. Am. Polit. Sci. Rev.112(3):542-63

Brooks C, Svallfors S. 2010. Why does class matter? Policy attitudes, mechanisms, and the case of the Nordic countries. Res. Soc. Stratif. Mobil. 28(2):199-213

Burgoon B, van Noort S, Rooduijn M, Underhill G. 2018. Positional deprivation and support for radical right and radical left parties. Econ. Policy 34(97):49-93

Busemeyer MR. 2015. Skills and Inequality: Partisan Politics and the Political Economy of Education Reforms in Western Welfare States. Cambridge: Cambridge University Press. Campbell AL. 2012. Policy Makes Mass Politics. Annu. Rev. Polit. Sci. 15:333-51 Canes-Wrone B. 2015. From Mass Preferences to Policy. Annu. Rev. Polit. Sci. 18:147-65 Ceobanu AM, Escandell X. 2010. Comparative Analyses of Public Attitudes Toward Immigrants and Immigration Using Multinational Survey Data: A Review of Theories and Research. Annu. Rev. Sociol. 36:309-28 
Chan TW, Goldthorpe JH. 2007. Class and Status: The Conceptual Distinction and its

Empirical Relevance. Am. Sociol. Rev. 72(4):512-32

Clark TN, Lipset SM. 1991. Are Social Classes Dying? Int. Sociol. 6(4):397-410

Clark TN, Lipset SM, Rempel M. 1993. The Declining Political Significance of Social Class.

Int. Sociol. 8(3):293-316

Cole ER. 2009. Intersectionality and research in psychology. Am. Psycholog. 64(3):170-80

Craig MA, Richeson JA. 2016. Stigma-Based Solidarity: Understanding the Psychological

Foundations of Conflict and Coalition Among Members of Different Stigmatized Groups.

Curr. Dir. Psycholog. Sci. 25(1):21-7

Cramer KJ. 2016. The Politics of Resentment: Rural Consciousness in Wisconsin and the Rise of Scott Walker. Chicagoo: University of Chicago Press

Crenshaw K. 1991. Mapping the Margins: Intersectionality, Violence against Women of Color. Stan. L. Rev. 43(6):1241-99

Curtis, J. 2016. Social Mobility and Class Identity: The Role of Economic Conditions in 33 Societies, 1999-2009. Eur. Sociol. Rev. 32(1):108-21

Dal Bó E, Finan F, Folke O, Persson T, Rickne J. 2019. Economic Losers and Political Winners: Sweden's Radical Right. Work. pap.

Dimick M, Rueda D, Stegmueller D. 2018. Models of Other-Regarding Preferences, Inequality, and Redistribution. Annu. Rev. Polit. Sci. 21:441-60

Druckman JN, Peterson E, Slothuus R. 2013. How Elite Partisan Polarization Affects Public Opinion Formation. Am. Polit. Sci. Rev. 107(1):57-79

Edlund J. 2007. Class conflicts and institutional feedback effects in liberal and social democratic welfare regimes. In The Political Sociology of the Welfare State. Institutions, 
Social Cleavages and Orientations, ed. S Svallfors, pp. 30-79. Stanford, CA: Stanford University Press

Edlund J, Lindh A. 2013. Institutional trust and welfare state support: on the role of trust in market institutions. J. Public Policy 33(3):295-317

Edlund J, Lindh A. 2015. The democratic class struggle revisited: the welfare state, social cohesion and political conflict. Acta Sociol. 58(4):311-28

Eidlin B. 2016. Why Is There No Labor Party in the United States? Political Articulation and the Canadian Comparison, 1932 to 1948. Am. Sociol. Rev. 81(3):488-516

Elsässer L, Hense S, Schäfer A. 2018. Government of the People, by the Elite, for the Rich: Unequal Responsiveness in an Unlikely Case. MPIfG Discussion Paper No. 18/5.

Enns PK. 2015. Relative Policy Support and Coincidental Representation. Perspect. Polit. 13(4):1053-64

Eribon D. 2013. Returning to Reims. Cambridge: MIT Press

Erikson RS. 2015. Income Inequality and Policy Responsiveness. Annu. Rev. Polit. Sci. 18:11-29

Erikson RS, MacKuen MB, Stimson JA. 2002. The Macro Polity. Cambridge: Cambridge University Press.

Evans G. 2017. Social Class and Voting. In The SAGE Handbook of Electoral Behavior, Vol. 1, eds. Arzheimer K, Evans J, Lewis-Beck MS, pp 177-98. Los Angeles: SAGE Evans G, Tilley J. 2017. The New Politics of Class: The Political Exclusion of the British Working Class. Oxford: Oxford University Press 
Fernández JJ, Jaime-Castillo AM. 2017. The Institutional Foundation of Social Class

Differences in Pro-Redistribution Attitudes: A Cross-National Analysis, 1985-2010. Soc.

Forces 96(3):1009-38

Finseraas H. 2009. Income inequality and demand for redistribution: A multilevel Analysis of European Public Opinion. Scand. Polit. Stud. 32(1):94-119

Fox C. 2012. Three Worlds of Relief: Race, Immigration, and the American Welfare State from the Progressive Era to the New Deal. Princeton: Princeton University Press

Fraser N. 1995. From Redistribution to Recognition? Dilemmas of Justice in a 'Post-Socialist' Age. New Left Rev. 1 (July-Aug): 68-93

Fraser N. 2009. Scales of Justice: Reimagining Political Space in a Globalizing World. New York: Columbia University Press.

Frymer P. 1999. Uneasy Alliances: Race and Party Competition in America. Princeton: Princeton University Press

Fussell E. 2014. Warmth of the Welcome: Attitudes Toward Immigrants and Immigration Policy in the United States. Annu. Rev. Sociol. 40:479-98

Gay C. 2006. Seeing Difference: The Effect of Economic Disparity on Black Attitudes Toward Latinos. Am. J. Polit. Sci. 50(4):982-97

Gelman A. 2018. Ethics in statistical practice and communication: Five recommendations. Significance 15(5):40-3

Gest J. 2016. The New Minority: White Working Class Politics in an Age of Immigration and Inequality. New York: Oxford University Press.

Gidron N, Hall PA. 2017. The Politics of Social Status: Economic and Cultural Roots of the Populist Right. Br. J. Sociol. 68:S57-S84 
Gilens M. 1999. Why Americans Hate Welfare: Race, Media, and the Politics of Antipoverty Policy. Chicago: University of Chicago Press.

Gilens M. 2012. Affluence and Influence: Economic Inequality and Political Power in America. Princeton: Princeton University Press.

Gilens M, Thal A. 2018. Doing Well and Doing Good? How Concern for Others Shapes Policy Preferences and Partisanship among Affluent Americans. Public Opin. Q. 82(2):20930.

Gingrich J. 2014. Visibility, Values, and Voters: The Informational Role of the Welfare State. J. Polit. 76(2):565-80

Gingrich J, Häusermann S. 2015. The decline of the working-class vote, the reconfiguration of the welfare support coalition and consequences for the welfare state. J. Eur. Soc. Policy. 25(1):50-75

Green J, McElwee S. 2019. The Differential Effects of Economic Conditions and Racial Attitudes in the Election of Donald Trump. Perspect. Polit.17(2):358-79.

Hemerijck A. 2013. Changing Welfare States. Oxford: Oxford University Press.

Hertel-Fernandez A. 2019. State Capture: How Conservative Activists, Big Businesses, and Wealthy Donors Reshaped the American States - and the Nation. New York: Oxford University Press

Hobolt SB. 2016. The Brexit vote: a divided nation, a divided continent. J. Eur. Public Policy. 23(9):1259-277

Hobolt SB, De Vries CE. 2016. Public Support for European Integration. Annu. Rev. Polit. Sci. 19:413-32 
Hooghe L, Marks G. 2018. Cleavage theory meets Europe's crises: Lipset, Rokkan, and the transnational cleavage. J. Eur. Public Policy 25(1):109-35

Hout M, Brooks C, Manza J. 1995. The Democratic Class Struggle in the United States, 1948-1992. Am. Sociol. Rev. 60(6):805-28

Houtman D. 2003. Lipset and "Working-Class" Authoritarianism. Am. Sociol. 34(1-2):85-103

Hochschild AR. 2016. Strangers in Their Own Land: Anger and Mourning on the American Right. New York: The New Press

Hooker J. 2016. Black Lives Matter and the Paradoxes of U.S. Black Politics: From Democratic Sacrifice to Democratic Repair. Polit. Theory 44(4):448- 69

Howard C. 1997. The Hidden Welfare State: Tax Expenditures and Social Policy in the United States. Princeton: Princeton University Press

Huber E, Stephens JD. 2001. Development and Crisis of the Welfare State: Parties and Policies in Global Markets. Chicago: University of Chicago Press

Hutchings VL, Valentino NA. 2004. The Centrality of Race in American Politics. Annu. Rev. Polit. Sci. 7:383-408

Häusermann S, Kriesi H. 2015. What do voters want? Dimensions and configurations in individual-level preferences and party choice. In The Politics of Advanced Capitalism. eds. Beramendi P, Häusermann S, Kitschelt H, Kriesi H. pp. 202-230. New York: Cambridge University Press

Inglehart R. 1990. Culture Shift in Advanced Industrial Society. Princeton: Princeton University Press Inglehart R, Rabier JR. 1986. Political Realignment in Advanced Industrial Society: From Class-Based Politics to Quality-of-Life Politics. Gov. Oppos. 21(4):456-79 
ISSP Research Group. 2015. International Social Survey Programme: National Identity III ISSP 2013. GESIS Data Archive, Cologne. ZA5950 data file version 2.0.0, doi:10.4232/1.12312

ISSP Research Group. 2016. International Social Survey Programme: Citizenship II - ISSP 2014. GESIS Data Archive, Cologne. ZA6670 data file version 2.0.0, doi:10.4232/1.12590 ISSP Research Group 2018. International Social Survey Programme: Role of Government V ISSP 2016. GESIS Data Archive, Cologne. ZA6900 data file version 2.0.0, doi:10.4232/1.13052

Iversen T, Soskice D. 2015. Information, Inequality, and Mass Polarization: Ideology in Advanced Democracies. Comp. Polit. Stud. 48(13):1781-1813

Iyengar S, Lelkes Y, Levendusky M, Malhotra N, Westwood SJ. 2019. The Origins and Consequences of Affective Polarization in the United States. Annu. Rev. Polit. Sci. 22:129-46 Jaime-Castillo AM, Marqués-Perales I. 2019. Social mobility and demand for redistribution in Europe: a comparative analysis. Br. J. Sociol. 70(1):138-65

Kenworthy L. 2014. Social Democratic America. Oxford: Oxford University Press Kesler C, Bloemraad I. 2010. Does Immigration Erode Social Capital? The Conditional Effects of Immigration-Generated Diversity on Trust, Membership, and Participation Across 19 Countries, 1981-2000. Can. J. Polit. Sci. 43(2):319-47

Kitschelt H, McGann AJ. 1995. The Radical Right in Western Europe: A Comparative Analysis. Ann Arbor: University of Michigan Press

Kitschelt H, Rehm P. 2014. Occupations as a Site of Political Preference Formation. Comp. Polit. Stud. 47(12):1670-1706 
Kitschelt HP, Rehm P. 2019. Secular Partisan Realignment in the United States: The Socioeconomic Reconfiguration of White Partisan Support since the New Deal Era. Polit. Soc. $47(3): 425-79$

Klar S. 2014. A Multidimensional Study of Ideological Preferences and Priorities among the American Public. Publ. Opin. Q. 78(S1):344-59

Klar S, Krupnikov Y, Ryan JB. 2018. Affective Polarization or Partisan Disdain? Untangling a Dislike for the Opposing Party from a Dislike of Partisanship. Public Opin. Q. 82(2):379-90 Kochan TA, Yang D, Kimball WT, Kelly EL. 2019. Worker Voice in America: Is There a Gap between What Workers Expect and What They Experience? ILR Rev. 72(1):3-38 Korpi W. 1983. The Democratic Class Struggle. London: Routledge and Kegan Paul Korpi W, Palme J. 1998. The Paradox of Redistribution and Strategies of Equality: Welfare State Institutions, Inequality, and Poverty in the Western Countries. Am. Social. Rev. 63(5):661-87

Korpi W, Palme J. 2003. New Politics and Class Politics in the Context of Austerity and Globalization: Welfare State Regress in 18 Countries, 1975-95. Am. Polit. Sci. Rev. $97(3): 425-46$

Kriesi H. 1998. The transformation of cleavage politics The 1997 Stein Rokkan lecture. Eur. J. Polit. Res. 33(2), 165-185

Kriesi H, Grande E, Dolezal M, Helbling M, Höglinger D, Hutter S, Wüest B. 2012. Political Conflict in Western Europe. Cambridge: Cambridge University Press.

Kuziemko I, Norton MI, Saez E, Stantcheva S. 2015. How Elastic Are Preferences for Redistribution? Evidence from Randomized Survey Experiments. Am. Econ. Rev. 105(4):1478-1508 
Kymlicka W, Banting KG. 2006. Multiculturalism and the Welfare State: Recognition and Redistribution in Contemporary Democracies. Oxford: Oxford University Press

Lamont M. 2000. The Dignity of Working Men: Morality and the Boundaries of Race, Class, and Immigration. Cambridge: Harvard University Press

Langsæther PE, Evans G, O'Grady T. 2019. Self-interest or socialization? A panel study of the mechanisms connecting class and political preference. Paper presented at the European Political Science Association's annual conference, Belfast, June 2019

Larsen CA, Dejgaard TE. 2013. The institutional logic of images of the poor and welfare recipients: A comparative study of British, Swedish and Danish newspapers. J. Eur. Soc. Policy. 23(3):287-99

Lareau A, Conley D. 2008. Social Class: How Does It Work?. New York: Russell Sage Foundation

Laurison D. 2016. Social Class and Political Engagement in the United States. Sociol. Compass. 10(8):684-97

Lax JR, Phillips JH, Zelizer A. 2019. The Party or the Purse? Unequal Representation in the US Senate. Am. Polit. Sci. Rev, 113(4):917-40

Lindh A, McCall L. 2019. Reconsidering the Popular Politics of Redistribution: Preferences for Reducing Economic Inequality in the U.S. Work. Pap.

Lilla M. 2018. The Once and Future Liberal: After Identity Politics. London: C. Hurst \& Co Lipset SM. 1960. Political Man: The Social Bases of Politics. New York: Doubleday \& Company Lipset SM, Rokkan S. 1967. Party Systems and Voter Alignments: Cross-National Perspectives. New York: Free Press 
Luce S. 2015. \$15 per Hour or Bust: An Appraisal of the Higher Wages Movement. New Labor Forum. 24(2):72-9

Lupu N, Pontusson J. 2011. The Structure of Inequality and the Politics of Redistribution. Am. Polit. Sci.Rev. 105(2):316-36

Manza J, Crowley N. 2018. Class Divisions and Political Attitudes in the 21st Century. In Handbook of Attitudes, Volume 2: Applications. eds. Albarracin D, Johnson BT. pp. 367-97. New York: Routledge

McCall L. 2016. Political and Policy Responses to Problems of Inequality and Opportunity: Past, Present, and Future. In The Dynamics of Opportunity in America. Evidence and Perspectives. eds. Kirsch I, Braun H. pp. 415-42. Cham: Springer

McCall L, Burk D, Laperrière M, Richeson JA. 2017. Exposure to rising inequality shapes Americans' opportunity beliefs and policy support. Proc. Natl. Academy Sci. 114(36):9593-8 McCall L, Kenworthy L. 2009. Americans' Social Policy Preferences in the Era of Rising Inequality. Perspect. Polit. 7(3):459-84

McCall L., Orloff AS. 2017. The multidimensional olitics of inequality: taking stock of identity politics in the US Presidential election of 2016. Br. J. Sociol. 68:S34-S56

McCarty N, Schickler E. 2018. On the Theory of Parties. Annu. Rev. Polit. Sci. 21:175-93 McDermott M, Knowles ED, Richeson JA. 2019. Class perceptions and attitudes toward immigration and race among working-class whites. Anal. Soc. Iss. Pub. Pol. 19(1):349-80 Meltzer AH, Richard SF. 1981. A Rational Theory of the Size of Government. J. Polit. Econ. 89(5):914-27

Mendelberg T, McCabe KT, Thal A. 2017. College Socialization and the Economic Views of Affluent Americans. Am. J. Polit. Sci. 61(3):606-23 
Mettler S, Soss J. 2004. The Consequences of Public Policy for Democratic Citizenship: Bridging Policy Studies and Mass Politics. Perspect. Polit. 2(1):55-73

Michener J. 2018. Fragmented Democracy: Medicaid, Federalism, and Unequal Politics. New York: Cambridge University Press

Milkman R. 2017. A New Political Generation: Millennials and the Post-2008 Wave of Protest. Am. Sociol. Rev. 82(1):1-31

Moene KO, Wallerstein M. 2001. Inequality, Social Insurance, and Redistribution. Am. Polit. Sci. Rev. 95(4):859-74

Moran M. 2018. (Un) troubling identity politics: A cultural materialist intervention. Eur. J. Soc. Theory, https://doi.org/10.1177/1368431018819722

Morel N, Palier B, Palme J. 2012. Towards a Social Investment Welfare State?: Ideas, Policies and Challenges. Bristol: Policy Press.

Morgan SL. 2018. Status Threat, Material Interests, and the 2016 Presidential Vote. Socius. $4: 1-17$

Morgan SL, Lee J. 2017. The White Working Class and Voter Turnout in US Presidential Elections, 2004 to 2016. Sociol. Sci. 4:656-85

Morgan SL, Lee J. 2019. Economic Populism and Bandwagon Bigotry: Obama-to-Trump Voters and the Cross Pressures of the 2016 Election. Socius. 5:1-15

Mudde C. 2004. The Populist Zeitgeist. Gov. Oppos. 39(4):541-63

Mudde C, Rovira Kaltwasser C. 2018. Studying Populism in Comparative Perspective: Reflections on the Contemporary and Future Research Agenda. Comp. Polit. Stud. 51(13):1667-93 
Mudge SL, Chen AS. 2014. Political Parties and the Sociological Imagination: Past, Present, and Future Directions. Annu. Rev. Sociol. 40:305-33

Mutz DC. 2018. Status threat, not economic hardship, explains the 2016 presidential vote. Proc. Natl. Academy Sci. 115(19):E4330-9

Naumann E, Stoetzer LF. 2018. Immigration and support for redistribution: survey experiments in three European countries. W. Eur. Polit. 41(1):80-101

Newman BJ, Hayes TJ. 2019. Durable Democracy? Economic Inequality and Democratic Accountability in the New Gilded Age. Polit. Behav. 41(1):5-30

Norris P, Inglehart R. 2019. Cultural Backlash: Trump, Brexit, and Authoritarian Populism. Cambrdige: Cambridge University Press

Oesch, D. 2008. Explaining Workers' Support for Right-Wing Populist Parties in Western Europe: Evidence from Austria, Belgium, France, Norway, and Switzerland. Int. Polit. Sci. Rev. 29(3):349-73

Oesch D, Rennwald L. 2018. Electoral competition in Europe's new tripolar political space: Class voting for the left, centre-right and radical right. Eur. J. Polit. Res. 57(4):783-807

Oliver JE, Rahn WM. 2016. Rise of the Trumpenvolk: Populism in the 2016 Election. Ann. Am. Acad. Polit. Soc. Sci. 667(1):189-206

Oskarson M, Demker M. 2015. Room for realignment: The working-class sympathy for Sweden Democrats. Gov. Oppos. 50(4):629-51

Page BI, Bartels LM., Seawright J. 2013. Democracy and the Policy Preferences of Wealthy Americans. Perspect. Polit. 11(1):51-73

Page BI, Gilens M. 2017. Democracy in America?: What has Gone Wrong and What We Can Do About It. Chicago: University of Chicago Press 
Pardos-Prado S, Xena C. 2019. Skill Specificity and Attitudes toward Immigration. Am. J. Polit. Sci. 63(2):286-304

Park B. 2017. How Are We Apart? Continuity and Change in the Structure of Ideological Disagreement in the American Public, 1980-2012. Soc. Forces. 96(4):1757-84

Pierson P. 1993. When Effect Becomes Cause: Policy Feedback and Political Change. World Polit. 45(4):595-628

Piketty T. 2020. Capital and Ideology. Cambridge: Harvard University Press

Piston S. 2018. Class Attitudes in America: Sympathy for the Poor, Resentment of the rich, and Political Implications. Cambridge: Cambridge University Press

Przeworski A, Sprague J. 1986. Paper Stones: A History of Electoral Socialism. Chicago: The University of Chicago Press

Putnam RD. 2007. E Pluribus Unum: Diversity and Community in the Twenty-first Century The 2006 Johan Skytte Prize Lecture. Scand. Polit. Stud. 30(2):137-74

Quadagno JS. 1994. The Color of Welfare: How Racism Undermined the War on Poverty. New York: Oxford University Press

Quillian L. 1995. Prejudice as a Response to Perceived Group Threat: Population Composition and Anti-Immigrant and Racial Prejudice in Europe. Am. Social. Rev. 60(4):586-611 Reeskens T, Van Oorschot W. 2012. Disentangling the 'New Liberal Dilemma': On the relation between general welfare redistribution preferences and welfare chauvinism. Int. J. Comp. Sociol. 53(2):120-39

Rehm P, Hacker JS, Schlesinger M. 2012. Insecure Alliances: Risk, Inequality, and Support for the Welfare State. Am. Polit. Sci. Rev. 106(2):386-406 
Ridgeway CL. 2014. Why Status Matters for Inequality. Am. Sociol. Rev. 79(1):1-16

Rodrik D. 2018. Populism and the Economics of Globalization. J. Int. Bus. Policy. 1(1-2):1233

Rooduijn M. 2019. State of the field: How to study populism and adjacent topics? A plea for both more and less focus. Eur. J. Polit. Res. 58(1):362-72

Rothstein B. 1998. Just Institutions Matter: The Moral and Political Logic of the Universal Welfare State. Cambridge: Cambridge University Press

Rueda D, Stegmueller D. 2019. Who Wants What?: Redistribution Preferences in Comparative Perspective. Cambridge: Cambridge University Press

Rydgren J. 2007. The Sociology of the Radical Right. Annu. Rev. Sociol. 33:241-62

Sartori G. 1969. From the Sociology of Politics to Political Sociology. Gov. Oppos. 4(2):195214

Schakel W. 2019. Unequal Policy Responsiveness in the Netherlands. Soc.-Econ. Rev. mwz018, https://doi.org/10.1093/ser/mwz018

Schmidt-Catran AW. 2014. Economic inequality and public demand for redistribution: combining cross-sectional and longitudinal evidence. Soc.-Econ. Rev. 14(1):119-40

Schmidt-Catran AW, Spies DC. 2016. Immigration and Welfare Support in Germany. Am. Sociol. Rev. 81(2):242-61

Schäfer A, Schwander H. 2019. 'Don't play if you can’t win': does economic inequality undermine political equality? Eur. Polit. Sci. Rev. 11(3):395-413

Sears DO, Funk CL. 1990. The limited effect of economic self-interest on the political attitudes of the mass public. J. Behav. Econ. 19(3):247-71 
Shapiro RY. 2011. Public Opinion and American Democracy. Public Opin. Q. 75(5):9821017

Sides J, Tesler M, Vavreck L. 2018. Identity Crisis: The 2016 Presidential Campaign and the Battle for the Meaning of America. Princeton: Princeton University Press

Skocpol T. 1991. Targeting Within Universalism: Politically Viable Policies to Combat Poverty in the United States. In The Urban Underclass. Eds. Jencks C, Peterson PE. pp. 41136. Washington, DC: The Brookings Institution

Solt F. 2008. Economic Inequality and Democratic Political Engagement. Am. J. Polit. Sci. $52(1): 48-60$

Sosnaud B, Brady D, Frenk SM. 2013. Class in Name Only: Subjective Class Identity, Objective Class Position, and Vote Choice in American Presidential Elections. Soc. Probl. 60(1):81-99

Soss J. 1999. Lessons of Welfare: Policy Design, Political Learning, and Political Action. Am. Polit. Sci. Rev. 93(2):363-80

Steele LG. 2016. Ethnic Diversity and Support for Redistributive Social Policies. Soc. Forces. 94(4):1439-81

Strolovitch DZ. 2007. Affirmative Advocacy: Race, Class, and Gender in Interest Group Politics. Chicago: University of Chicago Press.

Stubager, R. 2008. Education effects on authoritarian-libertarian values: a question of socialization. Br. J. Sociol. 59(2):327-50

Svallfors S. 2006. The Moral Economy of Class: Class and Attitudes in Comparative Perspective. Stanford: Stanford University Press 
Svallfors S. 2011. A Bedrock of Support? Trends in Welfare State Attitudes in Sweden, 1981-2010. Soc. Policy Adm. 45(7):806-25

Traber D, Hänni M, Giger N, Breunig C. 2019. What rich and poor consider important and how this matters for representation. Working paper.

Van Oorschot W. 2006. Making the difference in social Europe: deservingness perceptions among citizens of European welfare states. J. Eur. Soc. Policy. 16(1):23-42

Weaver VM, Lerman AE. 2010. Political Consequences of the Carceral State. Am. Polit. Sci. Rev. 104(4):817-33

Weeden J, Kurzban R. 2016. The Hidden Agenda of the Political Mind: How Self-Interest Shapes Our Opinions and Why We Won't Admit It. Princeton: Princeton University Press Weeden KA, Grusky DB. 2012. The Three Worlds of Inequality. Am. J. Sociol. 117(6):172385

Wodtke GT. 2017. Social Relations, Technical Divisions, and Class Stratification in the United States: An Empirical Test of the Death and Decomposition of Class Hypotheses. Soc. Forces 95(4):1479-1508

Wright EO. 2005. Approaches to Class Analysis. Cambridge: Cambridge University Press 


\section{SUPPLEMENTAL MATERIAL A: CLASS SCHEME}

For the empirical analyses in our article, we use the class scheme developed by Daniel Oesch (2006), which categorizes individuals into class positions based on their occupation and employment relationship (employee, self-employed, or employer). This scheme is similar to both the Erikson-Portocarero-Goldthorpe (EGP) scheme (Erikson \& Goldthorpe 1992) and the European Socio-economic Classification (ESeC) (Rose \& Harrison 2007) in the sense that the most fundamental distinction is between the middle class (commonly termed "the salariat" or "the service class") and the working class (Connelly et al. 2016). In addition, Oesch's scheme includes horizontal distinctions based on three different "work logics" - technical, organizational, and interpersonal. As illustrated in Table 1, this yields six different class segments.

Table 1. Class distinctions with examples of typical jobs/occupations

\begin{tabular}{|c|c|c|c|}
\hline \multirow[b]{2}{*}{ Hie rarchical } & \multicolumn{3}{|c|}{ Horizontal } \\
\hline & Technical & Organizational & Interpersonal \\
\hline Middle class & $\begin{array}{l}\text { Architects, engineers, } \\
\text { technicians. }\end{array}$ & $\begin{array}{l}\text { Accountants, } \\
\text { administrators, } \\
\text { managers. }\end{array}$ & $\begin{array}{l}\text { Teachers, nurses, } \\
\text { social workers. }\end{array}$ \\
\hline Working class & $\begin{array}{l}\text { Lorry drivers, machine } \\
\text { operators, mechanics. }\end{array}$ & $\begin{array}{l}\text { Clerks, receptionists, } \\
\text { secretaries. }\end{array}$ & $\begin{array}{l}\text { Cleaners, health care } \\
\text { assistants, shop } \\
\text { assistants. }\end{array}$ \\
\hline
\end{tabular}

We focus on four of these in our analyses: manual workers (bottom left), service workers (bottom right), managers, and business professionals (upper middle), and sociocultural professionals (upper right). There are two main reasons for this. The first is that recent research (as well as our own empirical analysis; see Supplemental Material C) suggests that the political preferences of technical experts (upper left) fall somewhere in between the other two middleclass segments. The classification of office workers (bottom middle) is likewise more complex 
than that of the other categories. Whereas Oesch (2006) views office workers as part of the working class, other theories assign this group to an "intermediate" hierarchical position (Erikson \& Goldthorpe 1992; Rose \& Harrison 2007). This complexity is reflected in the redistributive preferences of this segment, which tend to fall somewhere in between those of the middle class and the other working-class categories. For reasons of parsimony, we thus disregard these two class segments. The second reason for not focusing on technical experts and office workers is that these groups represent smaller shares of the labor force than the other four categories.

Another issue regarding the class scheme we rely on concerns the classification of the self-employed. Following Oesch (2006), we distinguish employers (ten or more employees) from self-employed professionals (with no or less than 10 employees) and from the selfemployed in working-class occupations (with no or less than 10 employees). In the 2016 data, the employer segment represents $1 \%$ of the sample and the median number of employees in this group is 20 . Thus, since this group mostly consists of owner-managers in relatively small businesses, we put these employers together with the managers and business professionals in our empirical analyses (excluding them does not substantively change the results for this category). Self-employed professionals are identified as part of the middle class on account of their professional status. Self-employed people in lower-skilled ocupations are assigned to a separate seventh class category of "own-account workers" (e.g. carpenters, drivers, hairdressers, shopkeepers). Predicted values for this relatively small (but significant) group of own-account workers is provided in Supplemental Material C. In addition, following much previous research, farmers and armed forces are excluded from the analysis, since they are difficult to fit into any of the other segments.

We want to underscore that it is common in this line of research to separate the upper middle class ("higher salariat" or "service class I") from the lower middle class ("lower 
salariat" or "service class II"). (For example, whereas a doctor is classified as upper middle class, a nurse is categorized as lower middle class.) There are significant differences in opinions between the upper class and the lower middle class; most notably, the upper middle class tends to be more conservative than the lower middle class on redistributive issues (see, e.g., Svallfors 1997). However, since the sample size of many country-specific datasets is relatively small, we cannot disaggregate the middle class hierarchically in a statistically reliable way in many countries (assuming that we also make horizontal distinctions). Nevertheless, it should be kept in mind that we depress the class polarization in preferences to a degree by not singling out the preferences of the upper middle class (e.g. the conservative economic preferences of higher-grade managers and executives) from the rest of the middle class.

Also notable is that we follow standard procedure by sorting individuals into classes based on their own current or last occupation (and employment relationship). Those that never have had a paid job are categorized based on their partner's occupation (and employment relationship), if any.

\section{SUPPLEMENTAL MATERIAL B: POLITICAL OPINION MEASURES}

\section{Redistribution and social insurance/services}

To measure economic preferences, we use the battery on government responsibilities from the ISSP Role of Government module, which has been fielded five times since 1985. We use the most recent wave collected in 2016, except for a few countires that were not included in this wave and for which we therefore have to use data from 2006.

The introduction statement reads "On the whole, do you think it should or should not be the government's responsibility to ...," FOLLOWED by a set of items asking about 
specific functions. The Likert-type response scale has four categories: "definitely should be," "probably should be,", "probably should not be," and "definitely should not be."

To measure support for redistribution, building on previous research (e.g., Svallfors 1997; Brooks \& Manza 2007), we constructed an index that adds together two of these items, namely, whether it is the government's responsibility to "reduce differences in incomes between rich and poor" and "provide a job for everyone who wants one." There is a relatively strong correlation between the two items in all countries, suggesting that to some degree they reflect a common underlying construct. The correlation (Pearson's R) is the strongest in Sweden at 0.50 and the weakest in Spain at (0.29). The index was constructed so that a higher score indicates stronger support for redistribution.

To take into account opinions regarding the role the government should play in protectng against insecurities related to sickness and old age, we created another index by adding together two other items in the same battery: whether it is the government's responsibility to "provide health care for the sick" and "provide a decent standard of living for the old." The two items are positively correlated, varying from 0.37 in Spain to 0.64 in the United States. The index was constructed so that a higher score indicates stronger support for government-sponsored protection.

Finally, it should be emphasized that scores on the two indices are positively related: the Pearson's R correlation is strongest in United States (0.54) and the weakest in Norway (0.27).

\section{Immigration}

To measure attitudes toward immigration, we use questions from the ISSP National Identity module, most recently fielded in 2013 , except for a few countries that were not included in this round and for which we therefore have to use data from 2003. As we did for the economic issues, 
we constructed an additive index from a set of individual items taken from a larger survey battery. The introduction statement to the battery reads "There are different opinions about immigrants from other countries living in [COUNTRY]. By 'immigrants' we mean people who come to settle in [COUNTRY]. How much do you agree or disagree with each of the following statements?" The Likert-type response scale has five categories: "Agree strongly," "agree," “neither agree nor disagree," "disagree," and "disagree strongly."

We constructed an index based on four items included in both the 2013 and 2003 waves of the survey (we had to use 2003 data for a few countries that did not participate in the 2013 wave): "Immigrants increase crime rates"; "immigrants are generally good for [COUNTRY'S] economy"; "immigrants take jobs away from people who were born in [COUNTRY]”; “immigrants improve [COUNTRY'S NATIONALITY] society by bringing new ideas and cultures."

With the exception of East Asian countries where the correlation is weaker (but still substantive), these four items are all strongly correlated in all countries, even though the strength of the correlation varied somewhat between countries and item pairs.

Two of the items ask about economic aspects of immigration and two about noneconomic aspects. Yet additional analyses suggest that the central patterns of class division are the same irrespective of whether we use a global measure or construct separate measures for specific aspects of immigration. Following much previous research, we thus chose to use a global measure in our primary empirical analysis. The index was constructed so that a higher score indicates more positive views toward immigration.

\section{Government responsiveness}

To measure perceptions of government responsiveness, we use data from the ISSP Citizenship module, most recently collected in 2014 , except for a few countries that were not included in this 
wave and for which we therefore have to use data from 2004. As for the other measures, we used a subset of items from a lagrer survey battery. In thise case, we used a battery that both asks about external and internal efficacy, the first gauging opinons about government responsiveness, the second assessing individuals" understanding of politics. The introduction statement reads "To what extent do you agree or disagree with the following statements?" The two items on external efficacy are formulated as follows: "People like me don't have any say about what the government does" and "I don't think the government cares much what people like me think." The Likert-type response scale has five categories: "Agree strongly," "agree," "neither agree nor disagree," "disagree," and "disagree strongly."

With the exception of France (zero correlation) and Japan (weak positive correlation), there is a relatively strong positive correlation (Pearson's R) between these two items, ranging from 0.40 (Spain and Switzerland) to 0.71 in Finland. The index was constructed so that a higher score indicates a stronger sense of government responsiveness.

\section{LITTERATURE CITED IN THE SUPPLEMENTAL MATERIALS}

Connelly R, Gayle V, Lambert PS. 2016. A Review of occupation-based social classifications for social survey research. Methodol. Innov. https://doi.org/10.1177/2059799116638003.

Brooks C, Manza J. 2007. Why Welfare States Persist: The Importance of Public Opinion in Democracies. Chicago: University of Chicago Press

Erikson R, Goldthorpe JH. 1992. The Constant Flux: A Study of Class Mobility in Industrial Societies. Oxford: Oxford University Press

Oesch D. 2006. Redrawing the class map: Stratification and institutions in Britain, Germany, Sweden and Switzerland. New York: Palgrave Macmillan

Rose D, Harrison E. 2007. The European socio-economic classification: a new social class schema for comparative European research. Eur. Soc. 9(3):459-90

Svallfors S. 1997. Worlds of welfare and attitudes to redistribution: A comparison of eight western nations. Eur. Sociol. Rev. 13(3):283-304 


\section{SUPPLEMENTAL MATERIAL C: PREDICTED VALUES}

Table 2. Predicted values support for economic redistribution. (Used for Figure 1 in the main article.)

\begin{tabular}{|c|c|c|c|c|c|c|c|}
\hline \multirow[b]{2}{*}{ Country } & \multicolumn{7}{|c|}{ Predicted Values with $95 \%$ Confidence Intervals } \\
\hline & Managers and business & Sociocultural professionals & Technical experts & Manual workers & Service workers & Office workers & Own-account workers \\
\hline All countries & $56.1(54.7-57.5)$ & $62.0(60.4-63.5)$ & $60.8(59.0-62.5)$ & $71.4(69.8-73.0)$ & $70.2(68.8-71.6)$ & $63.6(61.9-65.3)$ & $62.5(60.0-64.9)$ \\
\hline Australia (AU) & $44.6(36.5-52.7)$ & $51.3(42.1-60.4)$ & $53.0(43.1-62.9)$ & $66.9(55.2-78.5)$ & $66.1(58.4-73.9)$ & $49.5(40.0-59.0)$ & $50.8(39.4-62.2)$ \\
\hline Belgium (BE) & $65.2(60.6-69.9)$ & $67.6(62.5-72.7)$ & $73.0(66.5-79.4)$ & $80.5(75.4-85.5)$ & $77.4(72.6-82.1)$ & $71.7(66.6-76.8)$ & $79.3(69.3-89.4)$ \\
\hline Canada (CA) (2016) & $48.1(38.6-57.6)$ & $55.5(47.0-64.1)$ & $57.0(48.5-65.5)$ & $66.5(56.6-76.5)$ & $64.8(51.2-78.5)$ & $55.3(46.1-64.5)$ & $46.9(31.7-62.0)$ \\
\hline Denmark (DK) & $49.9(44.4-55.5)$ & $55.7(49.5-62.0)$ & $57.6(49.5-65.7)$ & $60.1(53.6-66.6)$ & $57.5(51.9-63.2)$ & $52.5(45.6-59.4)$ & $48.1(23.3-72.9)$ \\
\hline Finland (FI) & $58.1(52.6-63.6)$ & $61.0(55.2-66.9)$ & $62.3(56.1-68.6)$ & $75.1(69.5-80.7)$ & $76.5(71.3-81.6)$ & $64.0(56.9-71.1)$ & $66.9(56.4-77.4)$ \\
\hline France (FR) & $65.5(60.6-70.5)$ & $68.9(63.3-74.5)$ & $71.0(64.6-77.5)$ & $81.6(75.6-87.5)$ & $77.5(72.1-82.8)$ & $73.5(67.3-79.6)$ & $70.7(61.2-80.1)$ \\
\hline Germany (DE) & $60.4(56.2-64.6)$ & $66.4(62.0-70.9)$ & $61.9(57.2-66.6)$ & $73.6(69.4-77.8)$ & $75.4(71.3-79.5)$ & $66.8(62.2-71.4)$ & $71.0(61.8-80.2)$ \\
\hline Great Britain (GB) & $53.4(48.3-58.5)$ & $55.4(49.4-61.3)$ & $57.2(50.6-63.8)$ & $64.7(58.6-70.8)$ & $66.0(61.3-70.6)$ & $57.0(51.3-62.6)$ & $65.3(58.2-72.5)$ \\
\hline Ireland (IE) (2006) & $69.1(58.6-79.6)$ & $69.7(59.4-80.1)$ & $67.5(54.9-80.2)$ & $76.6(66.5-86.8)$ & $76.2(67.1-85.4)$ & $77.3(67.4-87.2)$ & $80.8(65.6-96.0)$ \\
\hline Japan (JP) & $48.3(42.1-54.5)$ & $51.0(44.6-57.3)$ & $57.4(49.9-64.9)$ & $60.0(54.2-65.7)$ & $58.6(53.4-63.8)$ & $52.7(47.1-58.3)$ & $55.6(46.1-65.0)$ \\
\hline Netherlands (NL) (2006) & $54.5(46.2-62.7)$ & $63.6(55.8-71.3)$ & $62.5(53.3-71.7)$ & $79.5(70.1-89.0)$ & $72.6(63.4-81.8)$ & $72.5(64.0-81.1)$ & $64.8(41.1-88.4)$ \\
\hline New Zealand (NZ) & $39.7(33.8-45.7)$ & $51.3(44.6-58.0)$ & $45.4(37.3-53.5)$ & $56.0(49.0-63.1)$ & $55.5(48.5-62.5)$ & $57.0(48.5-65.4)$ & $47.1(36.0-58.2)$ \\
\hline Norway (NO) & $65.4(60.2-70.6)$ & $72.5(66.6-78.4)$ & $68.1(61.9-74.4)$ & $79.9(73.7-86.2)$ & $79.6(74.3-85.0)$ & $76.9(70.3-83.5)$ & $71.2(60.2-82.3)$ \\
\hline South Korea (KR) & $54.8(49.4-60.3)$ & $57.5(52.1-63.0)$ & $60.3(52.6-68.1)$ & $62.3(56.0-68.5)$ & $59.9(54.4-65.4)$ & $54.5(48.9-60.0)$ & $56.3(50.2-62.4)$ \\
\hline Spain (ES) & $73.3(68.8-77.7)$ & $78.1(72.9-83.3)$ & $67.4(60.8-73.9)$ & $83.9(79.7-88.1)$ & $84.1(80.4-87.7)$ & $79.7(73.7-85.8)$ & $75.0(68.4-81.5)$ \\
\hline Sweden (SE) & $51.0(45.2-56.7)$ & $57.2(50.6-63.8)$ & $53.6(46.5-60.8)$ & $70.7(64.0-77.3)$ & $68.7(62.4-75.1)$ & $60.4(52.1-68.7)$ & $53.5(42.5-64.5)$ \\
\hline Switzerland $(\mathrm{CH})$ & $48.5(43.9-53.2)$ & $56.2(51.1-61.3)$ & $54.4(49.0-59.8)$ & $60.7(55.5-65.9)$ & $63.0(57.9-68.0)$ & $59.8(54.5-65.1)$ & $60.9(49.8$ - 71.9) \\
\hline United States (US) & $36.3(25.2-47.49$ & $44.0(33.0-55.0)$ & $43.1(30.7-55.5)$ & $51.9(40.7-63.1)$ & $48.8(37.9-59.7)$ & $44.5(32.6-56.4)$ & $41.1(28.7-53.4)$ \\
\hline
\end{tabular}

Source: International Social Survey Programme Role of Government 2016 (ISSP 2018). Data for CA, IE and NL is from 2006.

Notes: Additive index with scale $0-100$. These are predicted values based on country-specific linear OLS regressions with robust standard errors and controls for gender, age, geographical location (urban/rural), sector of employment (private/public), and religiosity. The predictions are for a middle-aged woman working in the private sector, that is non-religious and living in a small town. Based on multiple imputation by chained equations (20 datasets for each country). 
Table 3. Predicted values support for universal social protection. (Used for Figure 2 in the main article.)

\begin{tabular}{|c|c|c|c|c|c|c|c|}
\hline \multirow[b]{2}{*}{ Country } & \multicolumn{7}{|c|}{ Predicted Values with $95 \%$ Confidence Intervals } \\
\hline & Managers and business & Sociocultural professionals & Technical experts & Manual workers & Service workers & Office workers & Own-account workers \\
\hline All countries & $85.3(84.3-86.2)$ & $86.0(85.0-87.1)$ & $85.7(84.5-86.9)$ & $88.2(87.1-89.2)$ & $88.4(87.4-89.3)$ & $85.0(83.9-86.1)$ & $84.9(83.1-86.7)$ \\
\hline Australia (AU) & $87.0(83.3-90.8)$ & $89.4(84.6-94.2)$ & $89.2(83.9-94.5)$ & $93.2(88.1-98.3)$ & $93.1(89.4-96.8)$ & $90.8(86.1-95.6)$ & $88.5(82.0-95.0)$ \\
\hline Belgium (BE) & $90.9(88.1-93.6)$ & $91.3(88.2-94.5)$ & $91.4(87.3-95.5)$ & $94.4(91.3-97.5)$ & $95.1(92.4-97.9)$ & $91.3(88.4-94.1)$ & $92.3(85.9-98.7)$ \\
\hline Canada (CA) (2006) & $86.4(80.9-91.8)$ & $88.3(83.4-93.2)$ & $88.7(83.7-93.7)$ & $89.8(84.1-95.4)$ & $89.0(82.8-95.2)$ & $84.1(78.7-89.5)$ & $92.5(85.0-99.9)$ \\
\hline Denmark (DK) & $94.0(90.9-97.1)$ & $94.1(90.6-97.5)$ & $93.2(88.9-97.5)$ & $95.1(91.4-98.7)$ & $95.5(92.3-98.8)$ & $91.2(86.3-96.1)$ & $92.2(79.6-104.8)$ \\
\hline Finland (FI) & $88.3(84.9-91.7)$ & $89.0(85.6-92.5)$ & $91.5(87.8-95.2)$ & $91.5(88.0$ - 95.0) & $91.6(88.4-94.8)$ & $87.4(82.2-92.5)$ & $93.4(87.0$ - 99.9) \\
\hline France (FR) & $83.7(80.4-87.0)$ & $87.2(83.4-90.9)$ & $84.9(80.0-89.7)$ & $91.8(88.0$ - 95.5) & $86.7(83.0-90.3)$ & $88.6(84.9-92.2)$ & $85.2(79.4-91.1)$ \\
\hline Germany (DE) & $84.0(81.1-86.8)$ & $83.2(80.1-86.2)$ & $83.1(79.6-86.6)$ & $84.3(81.0$ - 87.5) & $85.8(82.6-89.0)$ & $85.0(81.7-88.4)$ & $80.5(74.0-86.9)$ \\
\hline Great Britain (GB) & $88.0(84.9-91.0)$ & $86.9(83.4-90.4)$ & $87.9(83.9-91.8)$ & $87.8(84.0$ - 91.6) & $87.8(84.8-90.8)$ & $87.6(84.3-90.9)$ & $89.6(85.4$ - 93.7) \\
\hline Ireland (IE) (2006) & $95.8(91.6-100.0)$ & $95.6(91.4-99.9)$ & $91.5(85.6-97.3)$ & $95.8(91.4-100.3)$ & $95.8(92.4-99.2)$ & $95.8(91.8-99.8)$ & $98.7(93.9-103.6)$ \\
\hline Japan (JP) & $66.8(61.4-72.2)$ & $71.5(65.9-77.0)$ & $65.6(59.4-71.9)$ & $70.2(65.0-75.5)$ & $75.4(70.7-80.1)$ & $71.4(66.2-76.6)$ & $73.6(65.3-81.8)$ \\
\hline Netherlands (NL) (2006) & $88.6(83.5-93.7)$ & $89.5(84.8-94.3)$ & $90.2(84.5-95.9)$ & $96.3(90.8-101.8)$ & $92.5(87.4-97.5)$ & $94.0(88.8-99.1)$ & $95.6(88.3-102.8)$ \\
\hline New Zealand (NZ) & $84.7(81.2-88.2)$ & $90.2(86.2-94.2)$ & $86.5(81.8-91.2)$ & $89.0(84.7-93.3)$ & $86.6(82.0-91.3)$ & $88.3(83.3-93.2)$ & $88.9(83.3$ - 94.5$)$ \\
\hline Norway (NO) & $96.3(94.0$ - 98.6) & $95.9(93.4-98.4)$ & $95.2(92.3-98.2)$ & $97.8(95.0-100.6)$ & $98.2(95.9-100.4)$ & $97.1(94.4-99.9)$ & $96.4(90.9-101.9)$ \\
\hline South Korea (KR) & $66.2(60.5-71.9)$ & $63.0(57.6-68.3)$ & $72.9(65.7-80.1)$ & $68.6(62.5-74.7)$ & $68.7(63.0-74.3)$ & $64.0(58.8-69.1)$ & $63.2(56.1-70.2)$ \\
\hline Spain (ES) & $91.8(89.0-94.5)$ & $92.2(88.8-95.6)$ & $89.6(84.9-94.3)$ & $92.9(90.2$ - 95.6) & $93.9(91.6-96.3)$ & $93.8(90.2-97.5)$ & $94.4(90.5-98.3)$ \\
\hline Sweden (SE) & $87.1(83.8-90.4)$ & $89.3(85.4-93.2)$ & $87.9(83.7-92.0)$ & $91.2(87.0$ - 95.4) & $91.5(87.9-95.1)$ & $91.1(86.3-96.0)$ & $86.0(77.7-94.3)$ \\
\hline Switzerland $(\mathrm{CH})$ & $77.5(73.5-81.4)$ & $78.5(74.5-82.5)$ & $79.2(74.8-83.6)$ & $79.5(75.1$ - 83.9) & $82.8(78.7-86.8)$ & $80.0(75.1-84.8)$ & $71.6(63.8-79.3)$ \\
\hline United States (US) & $75.6(67.6-83.6)$ & $80.4(72.4-88.4)$ & $79.2(70.7-87.7)$ & $79.7(71.5$ - 87.9) & $83.4(75.4-91.3)$ & $77.5(68.7-86.2)$ & $78.1(68.6-87.5)$ \\
\hline
\end{tabular}

Source: International Social Survey Programme Role of Government 2016 (ISSP 2018). Data for CA, IE and NL is from 2006. Notes: Additive index with scale $0-100$. These are predicted values based on country-specific linear OLS regressions with robust standard errors and controls for gender, age, geographical location (urban/rural), sector of employment (private/public), and religiosity. The predictions are for a middle-aged woman working in the private sector, that is non-religious and living in a small town. Based on multiple imputation by chained equations (20 datasets for each country). 
Table 4. Predicted values views on immigration. (Used for Figure 3 in the main article.)

\begin{tabular}{|c|c|c|c|c|c|c|c|}
\hline \multirow[b]{2}{*}{ Country } & \multicolumn{7}{|c|}{ Predicted Values with $95 \%$ Confidence Intervals } \\
\hline & Managers and business & Sociocultural professionals & Technical experts & Manual workers & Service workers & Office workers & Own-account workers \\
\hline All countries & $54.1(53.0-55.2)$ & $57.6(56.5-58.7)$ & $54.7(53.3-56.1)$ & $45.9(44.7-47.1)$ & $47.8(46.8-48.9)$ & $49.6(48.5-50.8)$ & $48.7(47.1-50.3)$ \\
\hline Australia (AU) (2003) & $62.6(59.9-65.3)$ & $64.4(61.3-67.6)$ & $62.3(58.5-66.1)$ & $56.2(52.8-59.6)$ & $54.9(52.0-57.8)$ & $55.0(52.0-58.1)$ & $53.6(49.7-57.5)$ \\
\hline Belgium (BE) & $45.0(41.1-48.8)$ & $47.4(43.0-51.8)$ & $47.8(42.7-53.0)$ & $35.8(31.7-39.9)$ & $38.1(34.2-42.0)$ & $41.6(37.6-45.6)$ & $39.2(32.7-45.6)$ \\
\hline Canada (CA) (2003) & $59.1(53.3-64.9)$ & $65.2(59.1-71.3)$ & $58.2(50.8-65.6)$ & $56.3(49.6-63.1)$ & $59.7(53.7-65.7)$ & $58.9(53.1-64.7)$ & $59.9(50.3-69.5)$ \\
\hline Denmark (DK) & $50.5(46.3-54.7)$ & $57.3(52.4-62.1)$ & $54.4(48.9-59.9)$ & $41.9(36.6-47.1)$ & $44.8(40.2-49.4)$ & $45.2(39.8-50.5)$ & $40.4(32.9-47.9)$ \\
\hline Finland & $56.5(52.2-60.8)$ & $56.5(51.5-61.5)$ & $54.0(48.8-59.2)$ & $41.2(36.5-45.9)$ & $48.4(44.1-52.8)$ & $49.9(44.5-55.3)$ & $49.2(42.2-56.2)$ \\
\hline France (FR) & $51.6(47.4-55.8)$ & $60.9(56.4-65.5)$ & $57.0(52.0-62.0)$ & $40.7(36.0-45.4)$ & $43.6(39.3-47.8)$ & $44.3(38.9-49.7)$ & $47.0(39.6-54.3)$ \\
\hline Germany (DE) & $57.4(54.2-60.7)$ & $61.6(58.0-65.3)$ & $60.9(56.7-65.1)$ & $49.9(46.2-53.6)$ & $50.5(47.0-54.0)$ & $55.2(51.2-59.2)$ & $51.3(42.4-60.2)$ \\
\hline Great Britain (GB) & $46.4(40.9-51.8)$ & $45.8(40.4-51.1)$ & $44.6(37.8-51.5)$ & $37.2(31.3-43.0)$ & $33.9(29.1-38.8)$ & $40.8(35.4-46.2)$ & $33.8(24.9-42.8)$ \\
\hline Ireland (IE) & $59.8(52.1-67.5)$ & $68.0(60.8-75.1)$ & $54.7(44.3-65.2)$ & $52.9(42.5-63.3)$ & $51.4(44.2-58.5)$ & $52.0(45.3-58.6)$ & $49.5(39.4-59.5)$ \\
\hline Japan (JP) & $53.3(48.9-57.7)$ & $55.5(50.5-60.5)$ & $53.6(47.9-59.3)$ & $48.6(44.1-53.2)$ & $52.4(48.7-56.1)$ & $51.3(47.2-55.3)$ & $51.5(45.2-57.8)$ \\
\hline Netherlands (NL) (2003) & $54.7(50.2-59.2)$ & $56.0(51.1-60.8)$ & $53.5(47.2-59.8)$ & $46.5(41.5-51.5)$ & $49.4(44.6-54.2)$ & $51.2(46.6-55.8)$ & $39.5(30.3-48.7)$ \\
\hline New Zealand (NZ) (2003) & $56.3(52.4-60.2)$ & $56.8(51.6-62.1)$ & $56.1(49.8-62.4)$ & $47.6(43.0-52.1)$ & $46.4(40.3-52.4)$ & $50.7(45.7-55.8)$ & $52.7(46.8-58.6)$ \\
\hline Norway (NO) & $53.7(50.5-56.8)$ & $57.2(53.7-60.7)$ & $55.7(51.6-59.7)$ & $47.4(43.2-51.5)$ & $50.3(46.9-53.8)$ & $52.6(47.7-57.6)$ & $55.6(48.9-62.3)$ \\
\hline South Korea (KR) & $49.7(46.0-53.5)$ & $49.7(46.2-53.2)$ & $46.8(42.5-51.2)$ & $45.8(42.5-49.1)$ & $48.6(45.5-51.7)$ & $47.7(44.1-51.3)$ & $46.9(43.6-50.1)$ \\
\hline Spain (ES) & $54.4(48.5-60.3)$ & $56.9(50.6-63.3)$ & $61.8(53.8-69.8)$ & $47.9(42.5-53.2)$ & $51.8(47.0-56.6)$ & $54.9(45.2-64.7)$ & $47.5(40.3-54.8)$ \\
\hline Sweden (SE) & $61.8(57.3-66.2)$ & $64.7(59.7-69.8)$ & $60.3(54.7-65.9)$ & $50.5(44.9-56.2)$ & $49.9(45.0-54.8)$ & $55.0(48.5-61.5)$ & $49.0(40.9-57.2)$ \\
\hline Switzerland (CH) & $58.1(54.6-61.6)$ & $62.3(58.5-66.1)$ & $57.0(52.7-61.2)$ & $53.0(48.7-57.3)$ & $52.8(49.2-56.5)$ & $51.6(47.6-55.7)$ & $56.6(51.7-61.6)$ \\
\hline United States (US) & $61.6(52.9-70.3)$ & $63.6(54.6-72.6)$ & $63.0(53.5-72.4)$ & $56.6(47.9-65.4)$ & $58.2(49.4-67.0)$ & $60.9(52.0-69.7)$ & $62.5(52.6-72.4)$ \\
\hline
\end{tabular}

Source: International Social Survey Programme National Identity 2013 (ISSP 2015). Data for AU, CA, NL and NZ is from 2003. Notes: Additive index with scale $0-100$. These are predicted values based on country-specific linear OLS regressions with robust standard errors and controls for gender, age, geographical location (urban/rural), sector of employment (private/public), and religiosity. The predictions are for a middle-aged woman working in the private sector, that is non-religious and living in a small town. Based on multiple imputation by chained equations (20 datasets for each country). 
Table 5. Predicted values perceptions of government responsiveness. (Used for Figure 4 in the main article.)

\begin{tabular}{|c|c|c|c|c|c|c|c|}
\hline \multirow[b]{2}{*}{ Country } & \multicolumn{7}{|c|}{ Predicted Values with $95 \%$ Confidence Intervals } \\
\hline & Managers and business & Sociocultural professionals & Technical experts & Manual workers & Service workers & Office workers & Own-account workers \\
\hline All countries & $44.7(43.4-46.1)$ & $46.6(45.1-48.1)$ & $45.7(43.9-47.4)$ & $33.7(32.2-35.2)$ & $36.1(34.7-37.4)$ & $38.4(36.9-39.9)$ & $37.7(35.4-40.1)$ \\
\hline Australia (AU) & $47.3(40.7-54.0)$ & $43.8(37.0-50.6)$ & $40.6(32.1-49.0)$ & $34.3(26.0-42.5)$ & $35.1(29.0-41.3)$ & $37.0(29.9-44.1)$ & $36.9(27.4-46.4)$ \\
\hline Belgium (BE) & $30.8(26.2-35.4)$ & $31.6(26.5-36.7)$ & $31.9(25.7-38.1)$ & $21.9(17.0-26.8)$ & $24.9(20.4-29.5)$ & $26.0(21.0-31.1)$ & $20.2(12.7-27.8)$ \\
\hline Canada (CA) (2004) & $38.3(31.8-44.8)$ & $40.9(33.4-48.4)$ & $32.5(24.2-40.8)$ & $29.5(21.9-37.1)$ & $25.4(18.5-32.2)$ & $32.3(25.0-39.6)$ & $41.3(28.2-54.4)$ \\
\hline Denmark (DK) & $43.6(38.7-48.4)$ & $42.8(37.1-48.5)$ & $42.5(35.9-49.2)$ & $30.9(24.6-37.2)$ & $33.7(28.2-39.1)$ & $40.5(34.4-46.6)$ & $40.4(30.7-50.0)$ \\
\hline Finland & $44.4(38.8-50.0)$ & $39.1(32.8-45.4)$ & $41.6(34.9-48.3)$ & $26.6(20.8-32.5)$ & $29.8(24.6-35.0)$ & $31.4(24.8-38.0)$ & $38.3(28.2-48.5)$ \\
\hline France (FR) & $56.6(52.6-60.6)$ & $58.8(54.1-63.4)$ & $58.8(53.3-64.2)$ & $51.2(46.0-56.3)$ & $53.4(49.0-57.8)$ & $48.9(43.4-54.3)$ & $54.3(45.4-63.3)$ \\
\hline Germany (DE) & $50.2(45.0-55.4)$ & $50.7(45.5-56.0)$ & $44.4(38.4-50.4)$ & $34.7(29.6-39.8)$ & $37.6(32.4-42.7)$ & $43.2(37.4-49.1)$ & $36.4(25.3-47.5)$ \\
\hline Great Britain (GB) & $40.1(35.1-45.0)$ & $41.9(36.5-47.2)$ & $43.8(37.1-50.5)$ & $33.3(27.9-38.7)$ & $29.6(25.5-33.8)$ & $32.4(27.4-37.4)$ & $32.0(25.6-38.4)$ \\
\hline Ireland (IE) (2004) & $36.7(24.2-49.2)$ & $34.0(20.7-47.4)$ & $32.9(17.2-48.6)$ & $25.1(12.9-37.3)$ & $26.0(14.9-37.2)$ & $23.7(12.5-34.9)$ & $18.4(0.9-35.8)$ \\
\hline Japan (JP) & $58.3(53.6-63.1)$ & $59.4(54.1-64.7)$ & $59.7(54.0-65.4)$ & $53.3(48.2-58.3)$ & $54.0(49.7-58.4)$ & $57.1(52.5-61.7)$ & $59.3(51.4-67.1)$ \\
\hline Netherlands (NL) & $39.9(31.6-48.3)$ & $45.3(37.1-53.5)$ & $46.4(37.5-55.3)$ & $27.9(18.1-37.6)$ & $29.6(20.6-38.6)$ & $33.0(24.4-41.7)$ & $26.4(13.4-39.3)$ \\
\hline New Zealand (NZ) (2004) & $40.7(35.6-45.3)$ & $46.3(40.9-51.8)$ & $43.3(36.0-50.7)$ & $34.7(28.7-40.7)$ & $36.1(30.7-41.5)$ & $38.1(31.1-45.1)$ & $42.7(35.7-49.6)$ \\
\hline Norway (NO) & $59.5(54.7-64.2)$ & $62.6(57.4-67.8)$ & $59.7(53.8-65.5)$ & $45.9(39.6-52.1)$ & $48.7(43.8-53.7)$ & $52.0(45.5-58.6)$ & $50.6(42.6-58.6)$ \\
\hline South Korea (KR) & $35.1(30.4-39.8)$ & $40.5(35.0-45.9)$ & $38.9(31.8-46.0)$ & $30.6(25.3-35.9)$ & $29.9(25.2-34.5)$ & $35.5(30.4-40.5)$ & $34.7(28.3-41.1)$ \\
\hline Spain (ES) & $35.3(30.8-39.9)$ & $37.1(31.4-42.7)$ & $35.5(28.4-42.6)$ & $28.7(24.0-33.4)$ & $30.7(26.0-35.5)$ & $34.1(28.3-39.8)$ & $27.4(21.2-33.7)$ \\
\hline Sweden (SE) & $56.4(50.3-62.6)$ & $58.1(51.2-65.1)$ & $58.9(51.6-66.1)$ & $44.1(36.4-51.9)$ & $45.4(38.6-52.2)$ & $51.0(43.4-58.7)$ & $53.8(41.8-65.7)$ \\
\hline Switzerland (CH) & $57.8(53.3-62.3)$ & $63.1(58.1-68.2)$ & $57.6(52.3-63.0)$ & $48.0(42.5-53.5)$ & $52.2(47.4-57.0)$ & $53.1(47.3-58.9)$ & $57.1(50.3-63.9)$ \\
\hline United States (US) & $32.3(21.9-42.7)$ & $37.7(27.3-48.1)$ & $34.5(23.4-45.5)$ & $25.7(15.2-36.2)$ & $25.2(15.2-35.3)$ & $30.0(18.5-41.4)$ & $27.3(14.6$ - 39.9$)$ \\
\hline
\end{tabular}

Source: International Social Survey Programme Citizenship 2014 (ISSP 2016). Data for CA, IE, and NZ is from 2004.

Notes: Additive index with scale $0-100$. These are predicted values based on country-specific linear OLS regressions with robust standard errors and controls for gender, age, geographical location (urban/rural), sector of employment (private/public), and religiosity. The predictions are for a middle-aged woman working in the private sector, that is non-religious and living in a small town. Based on multiple imputation by chained equations (20 datasets for each country). 